\title{
Mechanisms of Action of Microbial Biocontrol Agents against Botrytis cinerea
}

\author{
Rocío Roca-Couso ${ }^{1,2, *}$, José David Flores-Félix ${ }^{3, *(D)}$ and Raúl Rivas ${ }^{1,2,4}$ (D) \\ 1 Department of Microbiology and Genetics, Edificio Departamental de Biología, University of Salamanca, \\ 37007 Salamanca, Spain; raulrg@usal.es \\ 2 Institute for Agribiotechnology Research (CIALE), 37185 Salamanca, Spain \\ 3 CICS-UBI-Health Sciences Research Centre, University of Beira Interior, 6201-506 Covilhã, Portugal \\ 4 Associated Unit, University of Salamanca-CSIC (IRNASA), 37008 Salamanca, Spain \\ * Correspondence: rocioroca@usal.es (R.R.-C.); jdflores@usal.es (J.D.F.-F.)
}

Citation: Roca-Couso, R.;

Flores-Félix, J.D.; Rivas, R.

Mechanisms of Action of Microbial

Biocontrol Agents against Botrytis

cinerea. J. Fungi 2021, 7, 1045.

https://doi.org/10.3390/jof7121045

Academic Editor: Milena Cotorás

Received: 11 November 2021

Accepted: 4 December 2021

Published: 6 December 2021

Publisher's Note: MDPI stays neutral with regard to jurisdictional claims in published maps and institutional affiliations.

Copyright: (c) 2021 by the authors. Licensee MDPI, Basel, Switzerland. This article is an open access article distributed under the terms and conditions of the Creative Commons Attribution (CC BY) license (https:// creativecommons.org/licenses/by/ $4.0 /)$.

\begin{abstract}
Botrytis cinerea is a phytopathogenic fungus responsible for economic losses from USD 10 to 100 billion worldwide. It affects more than 1400 plant species, thus becoming one of the main threats to the agriculture systems. The application of fungicides has for years been an efficient way to control this disease. However, fungicides have negative environmental consequences that have changed popular opinion and clarified the need for more sustainable solutions. Biopesticides are products formulated based on microorganisms (bacteria or fungi) with antifungal activity through various mechanisms. This review gathers the most important mechanisms of antifungal activities and the microorganisms that possess them. Among the different modes of action, there are included the production of diffusible molecules, both antimicrobial molecules and siderophores; production of volatile organic compounds; production of hydrolytic enzymes; and other mechanisms, such as the competition and induction of systemic resistance, triggering an interaction at different levels and inhibition based on complex systems for the production of molecules and regulation of crop biology. Such a variety of mechanisms results in a powerful weapon against $B$. cinerea; some of them have been tested and are already used in the agricultural production with satisfactory results.
\end{abstract}

Keywords: Botrytis; biocontrol; mechanisms; Induced systemic resistance; biopesticide; rhizobacteria

\section{Introduction}

Agriculture is one of the main human activities at the economic level. It supplies food for a human population that is estimated to grow to reach 9 billion people by 2050 [1,2] Crop diseases are responsible for extreme economic losses, and they may be caused by different types of organisms [3]. It is estimated that at least $20-40 \%$ of these losses are caused by pathogenic infections, and they account for losses of USD 40 billion per year worldwide [4]. In fact, the FAO (Food and Agriculture Organization) estimates that 14\% of global crop production losses are due to plant diseases, with fungi accounting for $42 \%$ and bacteria for $27 \%$ [1].

Indeed, fungi are one of the most important threats to agriculture systems [5-7]. This is because they possess characteristics that make them dangerous, such as their high virulence, that is, the relative capacity of a microbe to cause damage to a host [8]. Additionally, fungi are known for their high reproductive potential, elevated dispersion, and ability to disseminate their reproductive forms, resulting in a great number of host individuals being infected in a short period of time [3]. In addition, they have the ability to survive under unfavorable conditions for long time periods because they are spore-forming microorganisms [9].

The most outstanding of all plant pathogenic fungi, which causes economic losses of USD 10 to 100 billion worldwide [10], is Botrytis cinerea, known for its ability to expand and colonize different crops $[6,11]$. Unlike other members of the Botrytis genus, it has a 
broad spectrum of hosts, infecting more than 1400 plant species [10,12]. It mainly uses dicotyledonous hosts, but it also can attack monocotyledonous hosts [13], and it affects a wide range of organs, including flowers, fruits, stems, and leaves [14]. Additionally, it has been reported to infect field- and greenhouse-grown horticultural crops before harvesting [15] and during the post-harvest storage [16]. In fact, B. cinerea is the main cause of agriculture losses during the postharvest period because of its unspecific host and the variety of organs it infects [17]. Its high virulence has been recently associated with a long terminal repeat retrotransposon called Boty and/or a DNA transposon called Flipper. This has resulted in a separation into four genetically different types of $B$. cinerea inside the species: Boty or Fliper, depending on which element it possesses; trasposa if it has both elements; and vacuma if it has none of them. The fungi that possess transposable elements are more virulent, and even those belonging to the Boty type are able to release small RNAs that knock out some plant defense genes [18].

B. cinerea, also known as gray mold [19], is the asexual form (anamorphic) of a necrotrophic fungus whose sexual form (teleomorphic) is called Botryotinia fuckeliana, an ascomycete [20]. It is a necrotrophic fungus, meaning that it induces plant cell death to ensure its nutrient supply [6]. Thus, it follows a stationary disease cycle, starting with conidia that are produced during the previous winter, airlifting on the host surface during spring [12,21], and attaching there through physical surface interactions [22]. Firstly, a weak attachment is formed through hydrophobic interactions between the host and conidial surfaces [23], followed by stronger binding resulting from conidia germination and the production of germ tubes, whose extracellular matrix acts as an adhesive to the host surface [22,24]. Conidial germination is dependent on several factors, with high humidity $(>93 \%)$ [25] and nutrient availability being the most important [12,26]. Additionally, some gases, such as ethylene, have been proven to induce germination [27,28]. After conidia germination, $B$. cinerea can penetrate tissues through active or passive invasion. This means that the fungus can take advantage of previous wounds and stomata for penetration or can directly attack healthy tissues [22]. At this level, invasion induces programmed cell death, a typical defense response against pathogens [29]. This is the consequence of the production of diffusible factors with phytotoxic activity, such as toxins, oxalic acid, and reactive oxygen species (ROS), which penetrate plant cells [30,31], allowing Botrytis to penetrate plant barriers [15]. Infection then expands to surrounding cells by degradation of the cell wall, leveraging the nutrients resulting from the process [32]. Finally, expansion continues until plant defenses have broken down, and Botrytis experiences vigorous growth, spreading disease [19] and resulting in plant maceration, fungal sporulation, and the production of new conidium [22].

Traditionally, chemical pesticides have been used for B. cinerea control [33]. However, in recent years, many arguments against their use have been raised [17]. These have mostly concerned environmental damage since pesticides accumulate in soils as toxic residues, as well as the development of resistance [16,34,35] resulting from pesticide overuse [36], and single-site fungicide use, which enhances the development of specific resistance [37]. This occurs because $B$. cinerea has a very short life cycle, a high reproductive tax, and high genetic variability, which make it a high-risk pathogen for the development of fungicide resistance [38].

Thus, biopesticides have been proposed as a potential alternative to treat this pathogen. Although there is no common definition for biopesticides, they can be described as plant pest control products manufactured from living microorganisms [39]. In recent years, they have achieved recognition because they present some positive characteristics, such as their higher selectiveness and their lower manufacturing costs [40]. Environmentally, they are also more efficient because their use does not release toxic compounds, and it decreases the negative effects of plant pathogens and increases positive responses by the plants [41]. Additionally, they usually have several modes of action, thus reducing the development of resistance [37], which is a key factor in Botrytis control owing to the quick development of resistance by this pathogen [38]. Unfortunately, biopesticides come 
with some disadvantages, such as a lower rate of kill compared with chemical pesticides, and they are negatively influenced by environmental conditions [40]. Therefore, another approach to pest control has been taken, which is the combination of biopesticides with chemicals, allowing maintenance or improvement of the control effect through a 10-fold reduction in the amount of pesticides and a reduction or elimination of residues [42]. This could also be a desirable strategy against the frequent appearance of strains resistant to numerous commercial chemical fungicides [43,44], which limits their implementation at a practical level [42].

Of the many different microorganisms, one type has been highly studied in the development of new biopesticides: plant-associated microorganisms, which are able to act as biopesticides and enhance plant growth at the same time [35,45]. These microorganisms are known as Plant Growth Promoting (PGP), and they are microbes living in the plant environment (inside plants' rhizosphere or phyllosphere) with the ability to improve plant development through different mechanisms [46]. It is known that endophytic populations usually come from rhizosphere populations, meaning that plants can establish associations with surrounding microorganisms without being harmed [47]. Additionally, they usually provide some kind of benefit to the plant, for example, through the production of phytohormones, such as auxins, cytokinins, and gibberellic acids [48]; the enhancement of uptake of essential elements, such as iron or phosphorus [49]; and the protection of plants against crop diseases [50]. Within the PGP microorganism family, endophytic microorganisms are those that inhabit the interior of plants, where they can contribute to the host's growth without causing disease [49]. These have been increasingly recognized because biocontrol efficiency is associated with important limiting factors-niche adaptation and microbial competition [1]. By using endophytes as biocontrol agents, these difficulties can be avoided since these organisms are already adapted to the target plant [51]. Endophytic populations vary from plant to plant and from species to species, and, within the same species, populations not only vary from region to region but also differ with changes in climatic conditions in the same region [49]. A great number of microorganisms have been described; however, most of them have only been tested under laboratory conditions. Thus, an analysis of in-vivo studies considering plant microorganism interactions is essential since the ideal conditions found in the laboratory are far from the reality in the field, where the development of beneficial microorganisms is affected by environmental issues, both biological and nutritional [52].

Several rhizospheric and endophytic microorganisms have been studied with regard to the development of new biopesticides, and currently, some of them are used for Botrytis control in crops where, owing to the impact, economic relevance, and intrinsic characteristics of this fungal phytopathogen, the use of biopesticides is a suitable tool for control that improves the sustainability of crop management [17]. Among the biopesticides, there are several species of bacteria, filamentous fungi, and yeasts that are already known to have antifungal activity [53,54], such as Bacillus subtilis and Trichoderma harzianum [38].

Among the bacteria in this group, the Bacillus genus is one of the most studied genera, mainly regarding its production of antibiotic substances, such as bacteriocins and peptide antibiotics, whose targets are closely related bacteria or subtilin, one of the bestcharacterized antibiotics produced by $B$. subtilis $[37,55]$. Species of this genus are considered biologically safe, and they are widely used in agriculture [56] because they possess several advantageous properties, such as spore formation, which allows them to survive under unfavorable conditions, for example, heat and drought conditions. Thus, they are highly desirable for use in industry production and storage, as these conditions do not jeopardize the viability and therefore the efficacy of the treatment [54]. Therefore, the Bacillus genus is considered one of most effective bacterial genera against phytopathogens [57]. However, there are other genera, such as Pseudomonas and Paenibacillus, which have also been wellstudied in regard to Botrytis biocontrol [58]. For example, Pseudomonas aeruginosa has been well-studied for its strong antagonistic effect against B. cinerea [59]. Paenibacillus as well as Bacillus is known to produce a large number of secondary metabolites, such as lipopeptide 
antibiotics, antifungal proteins, volatile compounds, and lytic enzymes [38]. In fact, it was originally included within Bacillus but later reclassified as a separate genus [60].

Regarding fungi, interest in them has increased because they possess biological characteristics that make them a suitable option; these include their high reproductive rate, both sexually and asexually; their short generation time; and their target-specific characteristic [61]. One of the most studied fungi is the Trichoderma genus owing to its multiple mechanisms of action, such as its induction of plant resistance, mycoparasitism, antibiosis, and competition for space and nutrients [37]. In fact, the first fungus registered as a biocontrol agent for plant disease with the United States EPA was T. harzianum ATCC 20476 in 1989. [1]. Other filamentous fungi, such as Gliocladium, are also known for their activity against Botrytis [58] and can directly attack the fungi through aggressive hyphal puncturing of cell walls [1]. Fungi produce several secondary metabolites with biocontrol interest or another biotechnological purposes, for example, biofuel production or commercial drugs [41].

Finally, yeasts have also been studied as biocontrol agents, mainly in fruits [7,62]. Yeasts present some advantages over bacteria, such as their simple nutritional requirements, their ability to colonize dry surfaces for long periods of time, and their fast growth [63]. They do not produce toxic metabolites; avoid negative environmental or toxicological impacts [64], unlike some bacteria [10,19]; and possess many different modes of action, including competition for nutrients and space, the production of toxins, enzyme secretion, the production of volatile organic compounds (VOCs), parasitism, and the induction of systemic resistance [65]. Some examples of yeasts with antagonistic activity against $B$. cinerea are Candida oleophila in apples after harvest [66], Pichia guilliermondii in tomato fruits, and Candida sake against major post-harvest apple pathogens [67].

B. cinerea is difficult to control because of its variety of attack modes, its ability to infect diverse hosts, and the ability of both its sexual and asexual stages to survive for extended periods under unfavorable conditions [10]. In this sense, the success of one single method is not likely, and 1 to 20 different methods are usually needed during one season [68]. Thus, knowing the mechanisms of action by which each microorganism interacts with pathogens is a key factor in the development of new biopesticides [38]. In conclusion, studying and understanding different modes of action are necessary to develop appropriate biopesticides [64].

In this review, we looked at the different mechanisms of action used for the biocontrol of the pathogen B. cinerea by both bacterial and fungal agents (Figure 1).

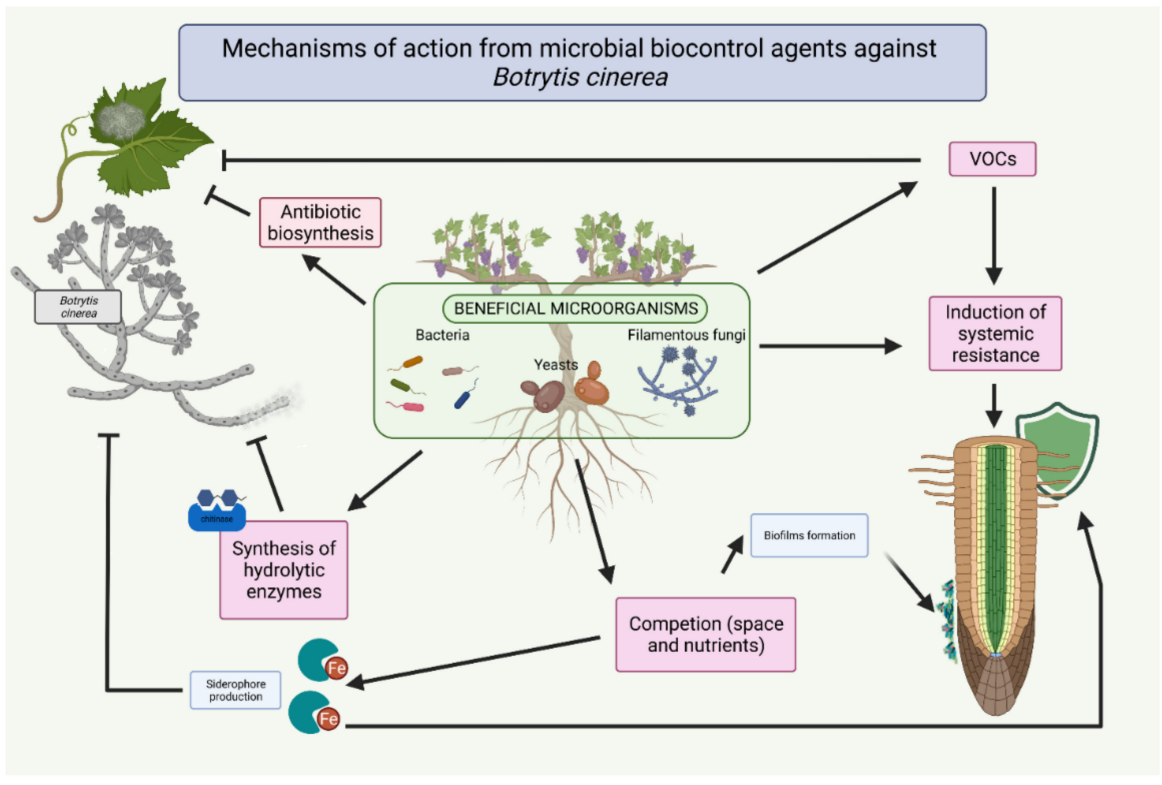

Figure 1. Mechanisms of action from microbial biocontrol agents against Botrytis cinerea. 


\section{Production of Diffusible Molecules}

Microorganisms can act against Botrytis by producing secondary metabolites that defend through the medium and reach the pathogen [69]. There are several antifungal molecule types, and in this review, we looked at two of the most important groups, as summarized in Table 1.

Table 1. Overview of literature reporting the inhibition of Botrytis cinerea through the production of diffusible antifungal metabolites.

\begin{tabular}{|c|c|c|c|c|}
\hline $\begin{array}{c}\text { Antifungal } \\
\text { Microorganisms }\end{array}$ & Condition/Plant & Antifungal Metabolite & Antifungal Effect & Reference \\
\hline \multicolumn{5}{|c|}{ Bacteria } \\
\hline $\begin{array}{l}\text { Actinoalloteichus } \\
\text { cyanogriseus 12A22 }\end{array}$ & In vitro & $\begin{array}{l}\text { 2-Hydroxyethyl-3-methyl- } \\
\text { 1,4-naphthoquinone }\end{array}$ & Growth inhibition & [70] \\
\hline $\begin{array}{l}\text { Bacillus amyloliquefaciens } \\
\text { VB7 }\end{array}$ & $\begin{array}{l}\text { In vitro and foliar } \\
\text { application }\end{array}$ & $\begin{array}{l}\text { Phthalic acid, hept-3-yl } \\
\text { isobutyl ester and propanoic } \\
\text { acid,2-hydroxy-, methyl ester }\end{array}$ & $\begin{array}{l}\text { Conidia parasitation- } \\
\text { Suppression of } \\
\text { mycelial growth }\end{array}$ & [71] \\
\hline Bacillus subtilis NCD-2 & Apple fruit & Fengycin & $\begin{array}{l}\text { Open pores in the } \\
\text { plasma membrane }\end{array}$ & [72] \\
\hline Bacillus velezensis Bvel1 & $\begin{array}{l}\text { Pepper and grape } \\
\text { plants }\end{array}$ & Bacillibactin & $\begin{array}{l}\text { Suppression of fungal } \\
\text { growth by chelating the } \\
\text { available ferric iron }\end{array}$ & [73] \\
\hline Bacillus velezensis XT1 & $\begin{array}{l}\text { In vitro and in fruits } \\
\text { (Tomatoes, grapes, } \\
\text { strawberries) }\end{array}$ & $\begin{array}{l}\text { Surfactin, fengycin, and } \\
\text { bacillomycin }\end{array}$ & $\begin{array}{l}\text { Open pores in the } \\
\text { plasma membrane }\end{array}$ & [56] \\
\hline $\begin{array}{c}\text { Kosakonia radicincitans } \\
\text { DSM } 16656\end{array}$ & $\begin{array}{l}\text { In vitro and in apple } \\
\text { fruit }\end{array}$ & Enterochelin & $\begin{array}{c}\text { Blocking the } \\
\text { polygalacturonase }\end{array}$ & [74] \\
\hline $\begin{array}{l}\text { Ochrobactrum cicero } \\
\text { MM17 }\end{array}$ & In vitro and Lilium L. & $\begin{array}{c}\text { Propanoic acid, } \\
\text {-hydoxy-methyl ester; } \\
\text { phthalic acid, hex-3-yl } \\
\text { isobutyl ester and phthalic } \\
\text { acid, hept-3-yl isobutyl ester }\end{array}$ & $\begin{array}{l}\text { Suppression of } \\
\text { mycelial growth }\end{array}$ & [75] \\
\hline Pantoea sp. MQT16M1 & $\begin{array}{l}\text { In vitro and in } \\
\text { strawberry fruits }\end{array}$ & $\begin{array}{c}\text { Salicylamide, maculosin, and } \\
\text { herniarin }\end{array}$ & $\begin{array}{l}\text { Disruption of cell wall } \\
\text { components }\end{array}$ & [76] \\
\hline $\begin{array}{c}\text { Paraburkholderia } \\
\text { phytofirmans PsJN } \\
\text { (Pseudomonas sp. PsJN) }\end{array}$ & In vitro & Lipopolysaccharides & Cytoplasm coagulation & {$[71]$} \\
\hline $\begin{array}{c}\text { Pseudomonas aeruginosa } \\
\text { 7NSK2 }\end{array}$ & $\begin{array}{l}\text { Tomato plants and } \\
\text { Arabidopsis thaliana }\end{array}$ & Pyochelin and pyocyanin & $\begin{array}{l}\text { Induction of systemic } \\
\text { resistance (ISR) }\end{array}$ & [77] \\
\hline $\begin{array}{l}\text { Pseudomonas fluorescens } \\
\text { fp-5 }\end{array}$ & Strawberry plants & $\begin{array}{l}\text { Hydroxamate-type } \\
\text { siderophores }\end{array}$ & $\begin{array}{l}\text { Prevention of plant } \\
\text { infection }\end{array}$ & [78] \\
\hline Pseudomonas sp. CHA0 & Soil & Pyoverdine or pseudobactin & Iron depletion & {$[50]$} \\
\hline Rahnella aquatilis BNM & In vitro & Enterochelin & $\begin{array}{c}\text { Blockage of } \\
\text { polygalacturonase }\end{array}$ & {$[79]$} \\
\hline \multicolumn{5}{|c|}{ Fungi } \\
\hline $\begin{array}{c}\text { Acremonium persicinum } \\
\text { MF-347833 }\end{array}$ & In vitro & VL-2397 (cyclic hexapeptide) & $\begin{array}{l}\text { Suppression of hyphal } \\
\text { elongation }\end{array}$ & [80] \\
\hline $\begin{array}{c}\text { Aspergillus fumigatus } \\
\text { AF293 }\end{array}$ & In vitro & Gliotoxin & DNA disruption & [81] \\
\hline Gliocladium virens 41 & In vitro & Gliotoxin & $\begin{array}{l}\text { Inhibition of spore } \\
\text { germination }\end{array}$ & [82] \\
\hline $\begin{array}{l}\text { Trichoderma atroviride } \\
\text { SJ3-4 }\end{array}$ & $\begin{array}{l}\text { In vitro and in } \\
\text { Phaseolus vulgaris cv. } \\
\text { Borlotto seeds }\end{array}$ & $\begin{array}{l}\text { Glucose oxidase dermadin, } \\
\text { trichovirdin and } \\
\text { sesquiterpene, heptalic acid }\end{array}$ & $\begin{array}{l}\text { Effect on spore } \\
\text { germination }\end{array}$ & [83] \\
\hline Trichoderma sp. BV1 & Rubus sp. & Gliotoxin & $\begin{array}{l}\text { Suppression of conidial } \\
\text { germination }\end{array}$ & [84] \\
\hline
\end{tabular}


Table 1. Cont.

\begin{tabular}{|c|c|c|c|c|}
\hline \multicolumn{5}{|c|}{ Yeasts } \\
\hline $\begin{array}{c}\text { Antifungal } \\
\text { Microorganisms }\end{array}$ & Condition/Plant & Antifungal Metabolite & Antifungal Effect & Reference \\
\hline $\begin{array}{l}\text { Aureobasidium pullulans } \\
\text { L47 }\end{array}$ & $\begin{array}{l}\text { Post-harvest grape } \\
\text { berries, kiwi fruit, and } \\
\text { strawberries }\end{array}$ & Aureobasidins & $\begin{array}{l}\text { Inhibition of inositol } \\
\text { phosphoryl ceramide } \\
\text { synthase }\end{array}$ & [85] \\
\hline $\begin{array}{c}\text { Metschnikowia pulcherrima } \\
\text { MPR3 }\end{array}$ & In vitro & Pulcherrimin & Iron sequestration & {$[64]$} \\
\hline $\begin{array}{c}\text { Pichia membranifaciens } \\
\text { CYC } 1106\end{array}$ & Apple fruits & Killer toxin & $\begin{array}{c}\text { Damage on membrane, } \\
\text { glucanase activity, } \\
\text { inhibition of } \\
\beta-1,3 \text {-glucansynthase, } \\
\text { cell cycle arrestation, } \\
\text { and inhibition of } \\
\text { calcium uptake }\end{array}$ & [86] \\
\hline $\begin{array}{l}\text { Rhodotorula glutinis ySL } \\
30\end{array}$ & In vitro & Rhodotorulic acid & $\begin{array}{c}\text { Inhibition of } \\
\text { polygalacturonase and } \\
\text { laccase }\end{array}$ & [87] \\
\hline $\begin{array}{c}\text { Saccharomyces cerevisiae } \\
\text { CBS8112 }\end{array}$ & Post-harvest pears & Killer toxin & $\begin{array}{l}\text { Damage to the } \\
\text { membrane, glucanase } \\
\text { activity, inhibition of } \\
\beta-1,3 \text {-glucansynthase, } \\
\text { cell cycle arrestation, } \\
\text { and inhibition of } \\
\text { calcium uptake }\end{array}$ & [88] \\
\hline
\end{tabular}

\subsection{Antimicrobial Molecules}

These are microbial compounds synthetized by microorganisms (bacteria or fungi) that, at low concentrations, are able to kill or inhibit the growth of other microorganisms [2,89]. They encompass a chemically heterogeneous group of organic, low-molecular-weight compounds produced by microorganisms that negatively affect the growth or metabolic activities of other microorganisms [38].

Regarding bacteria as antibiotic producers, some genera have been studied for their efficiency to act against B. cinerea, such as Bacillus and Pseudomonas [53]. On one hand, the genus Bacillus is known as one of the most efficient biocontrol agents against plant pathogens [90], as it produces important antimicrobial compounds, such as cyclic lipopeptides (LPs) [91]. These molecules are low-molecular-weight, cyclic, amphiphilic oligopeptides that are synthesized by enzyme complexes called Non-Ribosomal Peptide Synthetases (NRPSs) [56], and they have recently attracted attention for their broad-spectrum activity against plant pathogens [92]. They can be classified into three groups based on their amino acid sequence, with iturin and fengycin highlighted by their surfactant properties [38]. Additionally, other lipopeptide families, such as kurstakin, maltacines, and polymyxins, have been identified in Bacillus [93]. Lipopeptides are able to bind to the lipid membrane in cells, increasing their permeability and producing structural damage [38]. In particular, fengycin and iturin open pores in the plasma membrane [94], and it has been reported that they may damage the fungal hypha [95] and permeabilize fungal spores, thus inhibiting their germination [96].

As an example of Botrytis biocontrol mediated by Bacillus lipoproteins (LP), Bacillus sp. XT1 is able to inhibit the growth of the phytopathogen both in vitro and in vivo. In the first case, inhibition rates of 72, 48,30, and 19\% of the mycelium diameter were found after the application of $10,6,4$, and $2 \mathrm{mg} \mathrm{mL}^{-1}$, respectively, on lipopeptides. In-vivo assays developed in grapes, strawberries, and tomatoes infected with $B$. cinerea experienced a disease reduction in fruit treated with XT1 lipopeptides of 100,12, and 50\%, respectively, after Bacillus sp. XT1 lipopeptide treatment [56]. Another strain, B. subtilis NCD-2, has 
been shown to produce several secondary metabolites. Some of them, such as surfactin and fengycin, have antifungal activity against $B$. cinerea [72]. Surfactin is another LP with broad-spectrum antimicrobial activity [97]. However, lipoproteins are not the only antifungal metabolites produced by Bacillus; there are plenty of others, such as phthalic acid, hept-3-yl isobutyl ester, and propanoic acid, 2-hydroxy-, and methyl ester, produced by $B$. amyloliquefaciens VB7, which showed inhibition rates of up to $46 \%$ against $B$. cinerea [98]. On the other hand, Pseudomonas is also a genus that may control B. cinerea efficiently, since its members produce a wide range of metabolites [38], including 2,4-diacetylphloroglucinol (DAPG), pyrrolnitrin, and phenazine [2]. Another example is Paraburkholderia phytofirmans PsJN (previously classified as Pseudomonas $s p$. PsJN), which inhibits B. cinerea growth when both microorganisms are grown in the same plate. After microscopic observation, cytoplasm coagulation of $B$. cinerea mycelium was observed $[71,99]$. This produced mycelium degradation, fungal suppression, and hyphae structure modification [100].

Additionally, there are other bacterial genera that produce secondary metabolites with antifungal activity, for example, Actinoalloteichus cyanogriseus 12A22, which produces 2-hydroxyethyl-3-methyl-1,4-naphthoquinone, a compound whose inhibition of Botrytis is greater than that produced by amphotericin B, a wide-ranging antifungal compound [70]. Another example is Ochrobactrum ciceri MM17, which produces many different metabolites with antifungal activity, both diffusible and volatiles, such as propanoic acid, -hydroxymethyl ester, phthalic acid, hex-3-yl isobutyl ester and phthalic acid, hept-3-yl isobutyl ester (diffusible), and dimethyl trisulfide and pentadecane (VOC). These bacteria have also been tested against Botrytis, showing suppression of $77 \%$ of leaf blight [75]. Pantoea sp. MQT16M1 is also a great producer of antifungal metabolites, such as salicylamide, maculosin, and herniarin, allowing it to inhibit up to $80 \%$ of Botrytis mycelial growth [76]

Fungi can also produce antimicrobial molecules [2]. Some examples of such fungi are Nigrospora oryzae 2693 and N. oryzae 2778, Trichoderma asperellum 2739, Penicillium commune 2748 , Fusarium proliferatum 2751 , and Chaetomium globosum 2773 , whose secondary metabolites produced inhibition of $17,57,58,27,69$, and $56 \%$ of Botrytis, respectively [84]. Some antifungal molecules have been isolated and identified; for example, gliotoxin is produced by some species, such as Trichoderma sp. BV1 and Aspergillus fumigatus AF293, and it has antifungal activity related to DNA disruption [82,83]. Gliocladium virens 41 also produces gliotoxin, which has an inhibitory effect on B. cinerea spores germination [101]. Glucose oxidase is another secondary metabolite produced by T. atroviride SJ3-4 that also affects spore germination in B. cinerea, reducing it by up to $61 \%$ [86]. Indeed, Trichoderma produces several metabolites with antifungal activity that may be efficient for $B$. cinerea biocontrol, like dermadin, trichovirdin and sesquiterpene, heptalic acid [88]. The use of T. harzianum T-39 has also been effective in controlling infection in tomato plants in combination with the fungicide dicarboximide in a single application, reducing by half the treatments necessary to control the infection by B. cinerea [14].

In contrast, yeasts do not produce as many secondary metabolites as bacteria or filamentous fungi. In this sense, little is known about this mode of action in yeast. However, Aureobasidium sp. JYC1525, Saccharomyces cerevisiae JYC137, and Candida stellimalicola JYC2120, have been shown to reduce B. cinerea mycelial growth by $36.5,26.8$, and $14.5 \%$ respectively, by secreting diffusible compounds [19], and some metabolites have been studied and highlighted for their biocontrol activity [65]. Some of the most important of these are protein-like killer toxins, which are antimicrobial metabolites secreted by yeasts [86]. The first report of this activity was in S. cerevisiae CBS8112, but few yeasts have been shown to secrete killer toxins since then [88]. Additionally, Pichia membranifaciens CYC 1106 is able to produce killer toxins and has been studied for its biocontrol activity against B. cinerea [86]. Additionally, some other secondary metabolites with general antifungal activity have been described [65], such as aureobasidins, liamocins, 2-propylacrylic acid, and 2-methylenesuccinic acid, which are produced by Aureobasidium pullulans L47 [85]. 


\subsection{Siderophores}

Another large group of diffusible molecules with antifungal activity is the siderophores. These are low-molecular-weight organic molecules (200-2000 Da) that are involved in microbial iron metabolism [102]. Iron is an essential micronutrient that is present in a high percentage in soils. However, this element has extremely low solubility in common soil conditions ( $\mathrm{pH}>6)$, making its acquisition hard for living beings [52]. In this sense, iron bioavailability has become a limiting factor that may lead to competition among organisms. Siderophores are molecules with a high affinity for iron, allowing microorganisms to obtain this element [103]. Siderophores have been studied for their applications in a variety of fields, such as environmental science and medicine [104]. Regarding agriculture, they are not only used for biocontrol but also for soil fertility improvement. Biocontrol is achieved through iron sequestration. Siderophores are secreted and, under low-iron conditions, they form a ferric-siderophore complex that avoids acquisition by other microorganisms, reducing the availability of this micronutrient [105]. Under iron-deficient conditions, siderophore production may be a useful tool for phytopathogen inhibition in the host [103]. B. cinerea needs iron for growth. If iron availability is restricted, their spore germination rate and mycelial growth will decrease [106]. Some specific siderophores have been proven to have activity against these fungi, and they have been widely studied [38].

There are three main siderophore types, and according to which part of the molecule chelates the iron, they are classified into hydroxymates, catecholates, and carboxylates [107]. Some authors consider there are two other groups of siderophores: phenolates, which are included in the catecholate group, and mixed siderophores [108].

Hydroxymates are the most common siderophores [109]. They are produced by both bacteria and fungi, and their chelation site is a hydroxymate group (-CO-N(O-)-) that is synthetized from either lysine or ornithine. Lysine-derived examples are aerobactin, which is typically produced by Escherichia coli, and mycobactin, which is produced by Mycobacterium spp. [110]. On the other hand, ornithine derivatives include pyoverdine, known as a typical Pseudomonas siderophore; exochelin, which is a characteristic of Mycobacterium spp.; and ornibactin, which is also produced by some strains of Pseudomonas strain CHA0 [50]. Indeed, this genus produces a great number of secondary metabolites with antifungal activity against $B$. cinerea, for example, $P$. fluorescens $\mathrm{fp}-5$, which prevents plant infection after preharvest treatment thanks to its hydroxamate-type siderophores [78]. There are several examples of this type of siderophore with antifungal activity, such as pyoverdine or pseudobactin, which are both produced by Pseudomonas strain CHA0 and are able to suppress Fusarium oxysporum [50]. Fungi produce additional hydroxymate siderophores, like ferrichrome and fusarinine, produced by Fusarium spp., and coprogens, produced by Trichoderma spp. [111]. In fact, fungal siderophores mainly belong to this group, and they can be divided into three families according to their structure [112]. Fusarinines are either monomers, linear dimers or trimers, or cyclic trimers; coprogens are linear dihydroxamate and trihydroxamate ligands composed of fusarinine units and ferrichromes, which are cyclic hexapeptides [113-115]. Some of these fungal siderophores have been related to antifungal activity against other species [116]. For example, Acremonium spp. are endophyte fungi with siderophore activity, and some species, such as A. persicinum MF-347833, have shown antifungal effects against some phytopathogens, like $B$. cinerea $[80,117,118]$. Among yeasts, iron is also an essential nutrient, meaning iron depletion is a well-known mode of action against fungi [65]. An example from the hydroxymate group is rhodotorulic acid, a siderophore produced by Rhodotorula glutinis ySL 30 with activity against $B$. cinerea, which has been shown to delay spore germination and reduce apple decay by $72 \%[87,119]$. Another example is Metschnikowia pulcherrima MPR3, which has been shown to control Botrytis in vivo and is associated with iron sequestration [64] mediated by the siderophore pulcherrimin, known for its reddish coloring [120], which is widely produced among yeasts [121] However, pulcherrimin is not always considered a siderophore since it is not a diffusible compound [121]. 
The second group is catecholates, which are produced exclusively by bacteria. They possess a mono-, di-, or $\mathrm{C}_{6} \mathrm{H}_{5} \mathrm{OH}$-hydroxybenzoic acid group that chelates the iron $[107,122]$. The latter includes phenolates, which are mostly produced by enterobacteria [123]. Some of the most well-known members are enterobactin produced by E. coli, pyochelin produced by P. aeruginosa, salmochelin produced by Salmonella enterica, bacillibactin produced by Bacillus spp., agrobactin produced by Agrobacterium tumefaciens, parabactin produced by Paracoccus denitrificans, and azotobactin produced by Azotobacter vinelandii [107,124]. Members of Bacillus have been studied for their ability to produce siderophore-mediated antifungal activity by producing bacillibactin, which inhibits fungal growth against some pathogenic fungi, such as Macrophomina phaseolina, Fusarium moniliforme, and B. cinerea [73,125-127]. Moreover, $P$. aeruginosa $7 \mathrm{NSK}$ has a protective effect against $B$. cinerea when pyochelin and pyocyanin are produced together and when pyoverdine is produced, in tomato plants and Arabidopsis thaliana, respectively $[77,128]$. Additionally, siderophore production by other bacteria has been associated with antifungal activity against $B$. cinerea, for example, Kosakonia radicincitans, which produces enterochelin. In addition to iron sequestration, siderophores can achieve biocontrol through other pathways. For example, enterochelin, produced by the enterobacterium Rahnella aquatilis BNM, has been shown to inhibit $B$. cinerea by blocking polygalacturonase, a cell-wall-degrading enzyme that is involved in the colonization of host tissues [79]. Similar activity was shown when enterochelin produced by $K$. radicincitans DSM 16656 was tested against $B$. cinerea in apple fruits, reaching a decay reduction of 52\% [74]. Finally, Acinetobacter calcoaceticus HIRFA32 and Pseudomonas fluorescens Mst 8.2 produce a catechol-type siderophore that inhibits fungal mycelial growth by $46.9 \%$ in vitro and $71.5 \%$ in planta $[129,130]$.

Finally, carboxylates are only produced by a few bacteria, like certain Rhizobium spp. and Staphylococcus spp., and by fungi belonging to Mucorales [111]. Here, the chelation group is either a hydroxyl or carboxyl. Rhizobactin, produced by Rhizobium [131], and staphyloferrin, produced by Staphylococcus spp. [132], are highlighted in this group. Rhizobactin is also produced by some Zygomycetes fungi, it being the only group where fungal siderophores can be found, along with hydroxamates [112]. It has been related to biocontrol activity against some plant pathogens both in vitro and in vivo [133].

Additionally, siderophores have been also studied for their ability to stimulate plantinduced systemic resistance (ISR) in plants [38], making them more resistant to pathogens by inducing physiological changes throughout the entire plant [134]. This has been shown in studies of different bacteria, and siderophores from Pseudomonas have gained importance for their high iron affinity. Thus, pyoverdine and pyochelin have been studied against phytopathogenic fungi, such as B. cinerea [135]. These siderophores are highly related to ISR since it has been proven that repression of their synthesis increases plant susceptibility to $B$. cinerea [128]. In the same way, it has been found that P. syringae pv. tomato can trigger ISR in A. thaliana through production of the siderophore pseudobactin, and this has also been proven to positively influence $B$. cinerea disease reduction [136]. Therefore, determining how siderophores promote ISR remains poorly understood.

\section{Synthesis of Volatile Organic Compounds}

Volatile Organic Compounds (VOCs) are usually small, odorous compounds $(<\mathrm{C} 15)$ of low molecular mass $(<300 \mathrm{Da})$ with a high vapor pressure, low boiling point, and a lipophilic moiety. They belong to different chemical classes, such as terpenes and alcohols [137]. Some of them are known to interact with other microorganisms, and since they can travel long distances, they are considered good mechanisms of action for biocontrol [69]. However, these molecules have not received as much attention as other antagonistic mechanisms [103]. These molecules present some advantages over other mechanisms. For example, they are effective in low concentrations, they diffuse through air-filled pores in soil, and they can act on pathogens without establishing actual physical contact with them $[88,103]$. Additionally, they can also promote plant growth, enhance plant tolerance to abiotic stress, and elicit induced systemic resistance (ISR) [37]. 
Among bacteria, those in the genus Bacillus are known as great producers of secondary metabolites, including VOCs [103]. Some have been studied for their action against $B$. cinerea. Thus, Bacillus velezensis ZSY-1 has been identified as a producer of several volatile compounds, such as pyrazine (2,5-dimethyl), benzothiazole, phenol (4-chloro-3-methyl), and phenol-2,4-bis (1,1-dimethylethyl), whose inhibition rates against $B$. cinerea in vitro were found to be 100,100,100, and $91.19 \%$, respectively [138]. Recently, other members of the Bacillus genus, including B. nakamurai TR2, B. pseudomycoides DHT2, B. proteolyticus $\mathrm{H} 2 \mathrm{~F} 1$, and $B$. thuringiensis $\mathrm{H} 1 \mathrm{R} 2$, were found to produce VOCs against $B$. cinerea, such as 3-methylbutan-1-ol, sulfur-containing compounds, 2-heptanone, and dodecanal [139]. Additionally, the metabolome can be influenced by the presence of this pathogen. In this sense, $B$. amyloliquefaciens VB 7 produces extra VOCs, such as oxirane, 3,5-octadiyne, and formic acid, when it is co-cultured with $B$. cinerea biomass. This can be related to the antifungal activity shown both in vitro and in planta, which inhibited $46 \%$ of fungi [98].

In the same way, Pseudomonas spp. are also great metabolite producers [139]. For example, P. chlororaphis ZL3 was evaluated for its antifungal activity, and 23 VOCs were found [140]. In the same way, P. protegens CHAo was evaluated for inhibition of several fungi, being positive for those related to $B$. cinerea, because of the production of two volatile molecules, ammonia and dimethyl trisulfide [141]. Most experiments of this type have been performed in vitro. For example, P. aeruginosa LV, which produces phenazine-1-carboxylic acid, was shown to reduce Botrytis mycelial growth by $50 \%$ [142]. However, some in-vivo assays were also done. For example, the antifungal activity of $P$. fluorescens ZX due to VOCs was evaluated, showing that dimethyl trisulfide and geranyl formate treatment resulted in complete inhibition of the fungi [143].

Additionally, bacteria other than Bacillus and Pseudomonas have been studied for their antifungal VOC production. For example, Streptomyces sp. S97 was shown to inhibit $87 \%$ of B. cinerea symptoms resulting from the production of VOCs, mainly 3-carene 2,5dione, geosmin, beta-cubebene, and one phenolic compound [144]. Pantoea sp. MQT16M1 was also studied for its antifungal activity against Botrytis and was shown to reduce mycelial growth reduction by $90 \%$, owing to the production of VOCs, such as phenylethyl alcohol $[145,146]$. Finally, lactic acid bacteria like Lactiplantibacillus plantarum UFG 121 have also been shown to have antifungal activity against $B$. cinerea, reducing its concentration by $40-80 \%$, and this has been associated with a $\mathrm{pH}$ reduction, probably due to the production of phenyllactic acid and 4-hydroxyphenyllactic acid [147,148].

Fungi are also producers of VOCs, and they have been studied for their biocontrol activity against Botrytis. Some, like Hypoxylon sp. CI-4, an endophytic fungus isolated from Persea indica that produces 1,8-cineole and 1-methyl-1,4-cyclohexadiene, and alphamethylene-alpha-fenchocamphorone, have been tentatively identified among many others. Hypoxylon sp. CI-4 is known for displaying maximal VOC antimicrobial activity against Botrytis, resulting in 100\% inhibition [149]. M. anisopliae Ma70 has been shown to have antifungal activity against $B$. cinerea in vitro owing to the production of VOCs. Forty-one volatile compounds have been isolated, and one of them, 1-octanol, has been reported as an effective treatment for biocontrol since it inhibits conidia germination and mycelium growth of B. cinerea [150]. An unusual strain of Phomopsis sp. By254, isolated from Odontoglossum spp. (Orchidaceae), produces a mix of gases with antifungal properties against a wide range of plant pathogenic test fungi, including Botrytis [151]. Some VOCs have been identified, such as sabinene, 1-butanol, 3-methyl, benzeneethanol, 1-propanol, 2-methyl, and 2-propanone [152]. Finally, Trichoderma has also been studied for its volatilome, which has an antifungal effect, and some effective compounds, such as trichodermol, harzianum A, and harzianolide, have been discovered [101].

Regarding yeasts, there are also many species that show antifungal mechanisms of this type. Several yeasts, mostly food yeasts, such as $W$. anomalus, M. pulcherrima, $S$. cerevisiae, and A. pullulans EXF-6519, have VOC-derived antifungal activity against $B$. cinerea, with 3-methyl-1-butanol being the most effective compound $[65,153]$. Some of those VOCs have been identified, such as 2-ethyl-1-hexanol, which is produced by Sporidiobolus 
pararoseus YCXT3 and inhibits spore germination and mycelial growth [154], or 1, 3, 5, 7-cyclooctatetraene, 3-methyl- 1-butanol, 2-nonanone, and phenylethyl alcohol, which are produced by C. intermedia C410 [155]. Additionally, two of the most recently discovered microorganisms are Scheffersomyces spartinae W9 and Candida pseudolambica W16, which are VOC producers with B. cinerea antifungal activity, both in vitro and in planta [156].

Nowadays, hundreds of microorganisms have been described as VOC producers, and uncountable compounds have been isolated (Table 2) [157]. As previously stated, some VOCs have antifungal activity; however, the inhibitory effect is not always the same, as it depends on the specific relationship between the producer and the target [38]. Additionally, the quantity and diversity of volatile compounds produced by a specific microorganism vary depending on several factors, such as the availability of nutrients and oxygen [158]. In this sense, it can be concluded that VOCs and their effects cannot be associated with specific microbes, and their use as biofungicides must be specifically studied [159].

Table 2. Overview of literature reporting the inhibition of Botrytis cinerea by volatile antifungal metabolites production.

\begin{tabular}{|c|c|c|c|c|}
\hline $\begin{array}{c}\text { Antifungal } \\
\text { Microorganisms }\end{array}$ & Condition/Plant & Antifungal Metabolite & Antifungal Effect & Reference \\
\hline \multicolumn{5}{|c|}{ Bacteria } \\
\hline $\begin{array}{l}\text { Bacillus amyloliquefaciens } \\
\text { VB7 }\end{array}$ & $\begin{array}{l}\text { In vitro and foliar } \\
\text { application }\end{array}$ & $\begin{array}{l}\text { Phthalic acid, hept-3-yl } \\
\text { isobutyl ester and propanoic } \\
\text { acid,2-hydroxy-, methyl ester }\end{array}$ & $\begin{array}{l}\text { Conidia parasitation } \\
\text { Suppression of } \\
\text { mycelial growth }\end{array}$ & [98] \\
\hline $\begin{array}{c}\text { Bacillus nakamurai TR2, } \\
\text { Bacillus pseudomycoides } \\
\text { DHT2, Bacillus proteolyticus } \\
\text { H2F1 and Bacillus } \\
\text { thuringiensis H1R2 }\end{array}$ & $\begin{array}{l}\text { In vitro and in organic } \\
\text { tomato fruits }\end{array}$ & $\begin{array}{l}\text { 3-methylbutan-1-ol, } \\
\text { sulfur-containing } \\
\text { compounds, 2-heptanone, } \\
\text { and dodecanal }\end{array}$ & $\begin{array}{l}\text { Suppression of } \\
\text { mycelial growth }\end{array}$ & [139] \\
\hline Bacillus velezensis ZSY-1 & In vitro & $\begin{array}{c}\text { Pyrazine [2,5-dimethyl], } \\
\text { benzothiazole, phenol } \\
\text { (4-chloro-3-methyl), and } \\
\text { phenol-2,4-bis } \\
\text { (1,1-dimethylethyl) }\end{array}$ & $\begin{array}{l}\text { Suppression of mycelial } \\
\text { growth and sporulation }\end{array}$ & [138] \\
\hline $\begin{array}{l}\text { Lactiplantibacillus plantarum } \\
\text { UFG } 121\end{array}$ & $\begin{array}{l}\text { In vitro and in } \\
\text { kiwifruits }\end{array}$ & $\begin{array}{c}\text { Phenyllactic acid and } \\
\text { 4-hydroxyphenyllactic acid }\end{array}$ & $\begin{array}{l}\text { Suppression of } \\
\text { mycelial growth }\end{array}$ & [147] \\
\hline Pantoea sp. MQT16M1 & Grapevine plants & Phenylethyl alcohol & $\begin{array}{l}\text { Reduction of the length } \\
\text { of internal necrosis }\end{array}$ & [76] \\
\hline Pseudomonas aeruginosa LV & In vitro & Phenazine-1-carboxylic acid & $\begin{array}{l}\text { Suppression of } \\
\text { mycelial growth }\end{array}$ & [142] \\
\hline $\begin{array}{c}\text { Pseudomonas chlororaphis } \\
\text { ZL3 }\end{array}$ & $\begin{array}{l}\text { In vitro and in Chinese } \\
\text { cherry }\end{array}$ & $\begin{array}{l}\text { 1-dodecene and dimethyl } \\
\text { disulfide }\end{array}$ & $\begin{array}{l}\text { Reduction of disease } \\
\text { incidence and lesion } \\
\text { diameter }\end{array}$ & [140] \\
\hline Pseudomonas fluorescens ZX & In vivo and in grapes & $\begin{array}{l}\text { Dimethyl trisulfide and } \\
\text { geranyl formate }\end{array}$ & $\begin{array}{l}\text { Suppression of mycelial } \\
\text { growth and spore } \\
\text { germination. Reduction } \\
\text { of disease incidence } \\
\text { and the disease index }\end{array}$ & [143] \\
\hline $\begin{array}{c}\text { Pseudomonas protegens } \\
\text { CHAo }\end{array}$ & In vitro & $\begin{array}{l}\text { Ammonia and dimethyl } \\
\text { trisulfide }\end{array}$ & $\begin{array}{l}\text { Suppression of } \\
\text { mycelial growth }\end{array}$ & [141] \\
\hline Streptomyces sp. S97 & $\begin{array}{l}\text { In vitro and in } \\
\text { strawberries }\end{array}$ & $\begin{array}{l}\text { 3-carene 2,5-dione, geosmin, } \\
\text { beta-cubebene, and one } \\
\text { phenolic compound }\end{array}$ & $\begin{array}{l}\text { Inhibition of Botrytis } \\
\text { cinerea decay on } \\
\text { strawberries and } \\
\text { suppression of } \\
\text { germination }\end{array}$ & [144] \\
\hline
\end{tabular}


Table 2. Cont.

\begin{tabular}{|c|c|c|c|c|}
\hline \multicolumn{5}{|c|}{ Fungi } \\
\hline $\begin{array}{c}\text { Antifungal } \\
\text { Microorganisms }\end{array}$ & Condition/Plant & Antifungal Metabolite & Antifungal Effect & Reference \\
\hline Hypoxylon sp. CI-4 & In vitro & $\begin{array}{c}\text { 1,8-cineole, } \\
\text { 1-methyl-1,4-cyclohexadiene }\end{array}$ & $\begin{array}{l}\text { Suppression of } \\
\text { mycelial growth }\end{array}$ & [149] \\
\hline $\begin{array}{c}\text { Metarhizium anisopliae } \\
\text { Ma70 }\end{array}$ & $\begin{array}{l}\text { In vitro and in apple } \\
\text { fruits }\end{array}$ & 1-octanol & $\begin{array}{l}\text { Suppression of conidia } \\
\text { germination and } \\
\text { mycelium growth }\end{array}$ & [150] \\
\hline Phomopsis sp. By 254 & In vitro & $\begin{array}{l}\text { Sabinene, 1-butanol, } \\
\text { 3-methyl; benzene ethanol; } \\
\text { 1-propanol, 2-methyl, and } \\
\text { 2-propanone }\end{array}$ & $\begin{array}{l}\text { Suppression of } \\
\text { mycelial growth }\end{array}$ & [152] \\
\hline Trichoderma spp. & In vitro & $\begin{array}{l}\text { Trichodermol, harzianum A, } \\
\text { and harzianolide }\end{array}$ & $\begin{array}{l}\text { Suppression of } \\
\text { mycelial growth }\end{array}$ & [101] \\
\hline \multicolumn{5}{|c|}{ Yeasts } \\
\hline $\begin{array}{c}\text { Aureobasidium pullulans } \\
\text { EXF-6519 }\end{array}$ & $\begin{array}{l}\text { In vitro and in tomato } \\
\text { fruits and grapes }\end{array}$ & 3-methyl-1-butanol & $\begin{array}{l}\text { Suppression of mycelial } \\
\text { growth and reduction } \\
\text { of fungal incidence }\end{array}$ & [153] \\
\hline Candida intermedia C410 & $\begin{array}{l}\text { In vitro and in } \\
\text { strawberry fruits }\end{array}$ & $\begin{array}{c}\text { 1, 3, 5, 7-cyclooctatetraene, } \\
\text { 3-methyl- 1-butanol, } \\
\text { 2-nonanone, and phenylethyl } \\
\text { alcohol }\end{array}$ & $\begin{array}{l}\text { Suppression spore } \\
\text { germination and } \\
\text { mycelial growth }\end{array}$ & [155] \\
\hline $\begin{array}{c}\text { Scheffersomyces spartinae } \\
\text { W9, Candida pseudolambica } \\
\text { W16 }\end{array}$ & $\begin{array}{l}\text { In vitro and in } \\
\text { strawberry fruits in } \\
\text { planta }\end{array}$ & Unknown & $\begin{array}{l}\text { Suppression of } \\
\text { mycelial growth and } \\
\text { reduction of disease } \\
\text { incidence in fruits }\end{array}$ & [156] \\
\hline $\begin{array}{c}\text { Sporidiobolus pararoseus } \\
\text { YCXT3 }\end{array}$ & $\begin{array}{l}\text { In vitro and in } \\
\text { strawberry fruits }\end{array}$ & 2-ethyl-1-hexanol & $\begin{array}{l}\text { Suppression of spore } \\
\text { germination and } \\
\text { mycelial growth }\end{array}$ & [154] \\
\hline
\end{tabular}

\section{Hydrolytic Enzymes}

Another type of molecule that is highly involved in Botrytis biocontrol is the hydrolytic enzyme. These are able to cleave polymeric compounds, such as chitin, proteins, cellulose, hemicellulose, and even DNA [89], and they also can interfere with pathogen metabolic activity [160], inhibit conidia germination, and lyse germ tubes [58].

There is no specific composition for fungal cell walls, but most have a layered structure. While the innermost layer is relatively conserved, the outer layers are more heterogeneous [161]. In most fungal species, the inner cell wall composition is usually a core of covalently attached, branched $\beta$-[1,3] glucan and chitin [162]. This configuration is responsible for maintaining cell integration [161]. Biochemical analyses of $B$. cinerea cell walls have shown that they mainly constitute neutral sugars and proteins, with glucose, arabinose, galactose, xylose, and mannose being the most common neutral sugars present. Additionally, chitin and uronic acids have been detected [163]. In fact, microorganisms with the ability to cleave chitin are already used for the control of microbial pathogens and insect pests [34]. In summary, the main fungal cell wall components are chitin (around $20 \%$ ), glucans (between 50 and $60 \%$ ), and proteins (between 20 and 30\%) [103].

Therefore, glucan is the main constituent of Botrytis cell walls, and its degradation may result in its inhibition. This carbohydrate can be hydrolyzed by two main enzymes, exo- $\beta-1,3$-glucanase and endo- $\beta-1,3$-glucanase. The first is able to cleave glucose residuals from the non-reducer extreme, while the second acts in the bonds to aleatory sites along the polysaccharide chain [103]. Additionally, chitin hydrolyzation is a good biocontrol mechanism. Chitin is a non-branched homopolymeric $\mathrm{N}$-acetyl glucosamine with 1,4 bonds [164]. These links can be cleaved by two possible enzymes, exo-chitinase or $\mathrm{N}$-acetyl-b-glucosaminidase, which hydrolyzes the NAG extreme residues, and endo- 
chitinase, which randomly breaks link sites along the polymer chain [103]. Disruption of the main cell wall components may induce fungal suppression, so microorganisms that are able to produce related lytic enzymes are good candidates for biopesticide development (Table 3) [38].

Table 3. Overview of literature reporting the inhibition of Botrytis cinerea through hydrolytic enzyme production.

\begin{tabular}{|c|c|c|c|c|}
\hline Antifungal Microorganisms & Condition/Plant & Antifungal Metabolite & Antifungal Effect & Reference \\
\hline \multicolumn{5}{|c|}{ Bacteria } \\
\hline Bacillus amyloliquefaciens $\mathrm{Y} 1$ & In vitro & $\beta$-1,3-glucanase & $\begin{array}{l}\text { Suppression of mycelial } \\
\text { growth. Modification of } \\
\text { the hyphal structure }\end{array}$ & [165] \\
\hline $\begin{array}{l}\text { Bacillus halotolerans KLBC } \\
\text { XJ-5 }\end{array}$ & $\begin{array}{l}\text { In vitro and in } \\
\text { strawberry fruits }\end{array}$ & $\begin{array}{l}\text { Chitinase and } \beta-1 \text {, } \\
\text { 3-glucanase }\end{array}$ & $\begin{array}{l}\text { Suppression of mycelial } \\
\text { growth and reduction of } \\
\text { conidial germination }\end{array}$ & [166] \\
\hline Bacillus subtilis KLBC BS6 & $\begin{array}{l}\text { In vitro and in } \\
\text { blueberry fruits }\end{array}$ & Chitinase & $\begin{array}{l}\text { Suppression of mycelial } \\
\text { growth and reduction of } \\
\text { conidial germination }\end{array}$ & [167] \\
\hline $\begin{array}{l}\text { Paenibacillus xylanexedens } \\
\qquad \mathrm{Z} 2-4\end{array}$ & In vitro & Chitinase & $\begin{array}{l}\text { Suppression of mycelial } \\
\text { growth }\end{array}$ & [168] \\
\hline Pseudomonas elgii HOA73 & In vitro & Chitinase & $\begin{array}{l}\text { Suppression of spore } \\
\text { germination }\end{array}$ & {$[34]$} \\
\hline Serratia plymuthica C48 & In vitro & Chitinase & $\begin{array}{l}\text { Suppression of spore } \\
\text { germination and } \\
\text { germ-tube elongation }\end{array}$ & [169] \\
\hline $\begin{array}{l}\text { Virgibacillus marismortui } \\
\text { M3-23, Terribacillus halophilus } \\
\text { J31, Halomonas elongate L80, } \\
\text { Planococcus rifietoensis M2-26, } \\
\text { Staphylococcus equorum B1-35 } \\
\text { and Staphylococcus sp. J23 }\end{array}$ & $\begin{array}{l}\text { In vitro and in } \\
\text { strawberry fruits }\end{array}$ & $\begin{array}{l}\text { Chitinase, } \beta-1,3 \text {-glucanase, } \\
\text { cellulase and protease }\end{array}$ & $\begin{array}{l}\text { Reduction of gray mold rot } \\
\text { incidence and fungal } \\
\text { growth }\end{array}$ & [170] \\
\hline \multicolumn{5}{|c|}{ Fungi } \\
\hline Albifimbria verrucaria SYE-1 & $\begin{array}{c}\text { In vitro and in grape } \\
\text { leaves }\end{array}$ & Chitinase & $\begin{array}{l}\text { Suppression of conidium } \\
\text { germination and mycelial } \\
\text { growth }\end{array}$ & {$[171]$} \\
\hline Gliocladium roseum Bainier & In vitro & $\beta$ l-3 glucanase & $\begin{array}{c}\text { Breakdown of glucans in } \\
\text { hyphal walls }\end{array}$ & [172] \\
\hline Gliocladium virens 41 & In vitro & Endochitinase & $\begin{array}{c}\text { Suppression of spore } \\
\text { germination and hyphal } \\
\text { elongation }\end{array}$ & [173] \\
\hline $\begin{array}{l}\text { Trichoderma harzianum } \\
\text { NCIM1185 }\end{array}$ & Bean leaves & Extracellular proteases & $\begin{array}{l}\text { Inactivation of fungal } \\
\text { hydrolytic enzymes and } \\
\text { attack of fungal cell wall } \\
\text { components }\end{array}$ & [174] \\
\hline Trichoderma harzianum T39 & Bean leaves & $\begin{array}{c}\text { Exo- and } \\
\text { endo-polygalacturonase, } \\
\text { pectin methyl esterase, } \\
\text { pectate lyase, cutinase, } \\
\text { chitinase, and } \\
\beta-1,3 \text {-glucanase }\end{array}$ & $\begin{array}{l}\text { Reduction of spore } \\
\text { germination }\end{array}$ & [175] \\
\hline
\end{tabular}


Table 3. Cont

\begin{tabular}{|c|c|c|c|c|}
\hline Antifungal Microorganisms & Condition/Plant & Antifungal Metabolite & Antifungal Effect & Reference \\
\hline \multicolumn{5}{|c|}{ Yeasts } \\
\hline Aureobasidium pullulans PI1 & $\begin{array}{l}\text { In vitro and in grape } \\
\text { and mandarin fruits }\end{array}$ & $\begin{array}{l}\beta-1,3 \text {-glucanase, pectinase, } \\
\text { and protease }\end{array}$ & $\begin{array}{l}\text { Disruption of cell wall } \\
\text { components and } \\
\text { competition for nutrients }\end{array}$ & {$[63]$} \\
\hline Aureobasidium pullulans PL5 & In vitro & Alkaline serine protease & $\begin{array}{l}\text { Reduction of spore } \\
\text { germination and } \\
\text { germ-tube length }\end{array}$ & [176] \\
\hline $\begin{array}{l}\text { Galactomyces candidum } \\
\text { JYC1146 }\end{array}$ & $\begin{array}{l}\text { In vitro and in } \\
\text { strawberry fruits }\end{array}$ & Chitinase & $\begin{array}{l}\text { Control of fungal growth } \\
\text { and reduction of disease } \\
\text { severity }\end{array}$ & [19] \\
\hline Pichia anomala $\mathrm{K}$ & Apple fruits & Exo- $\beta$-glucanases & $\begin{array}{c}\text { Disruption of cell wall } \\
\text { components }\end{array}$ & [177] \\
\hline Cryptococcus laurentii LS28 & Apple fruits & $\beta$-1,3-glucanase & $\begin{array}{l}\text { Reduction of disease } \\
\text { appearance in postharvest } \\
\text { conditions }\end{array}$ & [178] \\
\hline
\end{tabular}

The genera Bacillus and Pseudomonas are considered to be two of the most efficient antagonists in phytopathogen control owing to the direct action of chitinase [103]. Regarding the genus Bacillus, studies on B. halotolerans KLBC XJ-5 have shown that this strain undergoes chitinase and $\beta-1,3$-glucanase secretion, and this has been linked with its ability to reduce $B$. cinerea mycelial growth and conidial germination [166]. In the same way, Bacillus amyloliquefaciens $\mathrm{Y} 1$ antifungal activity has been related to the production of hydrolytic enzymes, such as $\beta-1,3$-glucanase [165]. Bacillus subtilis KLBC BS6 has also been shown to exhibit antifungal activity against $B$. cinerea through several mechanisms, including chitinase production [167]. Additionally, Paenibacillus xylanexedens Z2-4 is a chitinase producer with antifungal activity against several pathogens, such as B. cinerea [168]. On the other hand, Pseudomonas spp. are also interesting. For example, P. elgii HOA73 possesses strong chitinolytic activity, which is associated with the complete suppression of spore germination of $B$. cinerea in vitro [34].

Species, including those in other genera, such as Virgibacillus marismortui M3-23, Terribacillus halophilus J31, Halomonas elongata L80, Planococcus rifietoensis M2-26, Staphylococcus equorum B1-35, and Staphylococcus sp. J23, which produce chitinase, $\beta-1,3$-glucanase, cellulase, and protease, have also shown in-vitro Botrytis antifungal activity related to the production of hydrolytic enzymes. They reduce the concentrations of these enzymes by 50 to $92 \%$ in infected fruits [38,170]. These activities have also been studied in planta in some species. For example, Serratia plymuthica C48, which inhibits spore germination and germ-tube elongation, is a high chitinolytic enzyme producer. Studies performed on this strain have purified two main enzymes, CHIT60 and CHIT100, and these have been tested for their potential use in Botrytis biocontrol by analyzing spore germination and germtube elongation. Results showed reductions of 28 and $31.6 \%$, respectively, when applying CHIT60 and reductions of 78 and 63.9\%, respectively, when applying CHIT100 [169].

Regarding fungal agents that act against Botrytis, one of the most well-known agents of Botrytis control is T39 of T. harzianum, which is able to produce proteases that hydrolase some essential Botrytis enzymes, like exo- and endo-polygalacturonase, pectin methyl esterase, pectate lyase, cutinase, chitinase, and $\beta$-1,3-glucanase, reducing spore germination [175]. Extracellular proteases are also produced by Trichoderma spp., and they have recently received more attention since they play an important role in acting against phytopathogens. They have been tested against $B$. cinerea and found to act in different ways. They can inactivate the fungal hydrolytic enzymes needed for infection, they are useful for protein competition, and they can also directly attack components of fungal cell walls, facilitating cell disruption $[174,179]$. This is not the only species with this capacity; several additional species have been tested for their biocontrol in vivo [180]. Some fungi, like Gliocladium, have been highlighted for their production of hydrolytic enzymes, like 
endochitinase in G. virens 41 or $\beta$ 1-3 glucanase and chitinase produced by G. roseum Bainier, resulting in a reduction of Botrytis growth of up to $90 \%$ [172,173]. Additionally, new endophytes are being discovered; Albifimbria verrucaria SYE-1 was recently isolated from grape leaves, and chinolytic activity against $B$. cinerea has been reported [171].

Finally, yeasts also secrete lytic enzymes, such as chitinases, proteases, and glucanases, which are involved in biocontrol activity. As previously stated, chitin is a key factor in fungal cell wall degradation, and in this sense, some genera, such as Aureobasidium, Candida, Debaryomyces, Metschnikowia, Meyerozyma, Pichia, Saccharomyces, Tilletiopsis, and Wickerhamomyces, have been studied for their chitinolytic activity [65]. Specifically, Galactomyces candidum JYC1146 and Aureobasidium sp. JYC1525 have shown chitinolytic activity that may be involved in Botrytis biocontrol [19]. However, Aureobasidium pullulans PI1 has also been studied for its ability to excrete $\beta$-1,3-glucanase, pectinase, and protease to the medium. While $\beta$-1,3-glucanase and protease enzymes act directly on the Botrytis cell wall, pectinase has the ability to penetrate and colonize plant cell walls, thus enhancing its ability to compete with pathogens for nutrients [63]. Indeed, glucanase activity against Botrytis has been well-studied in yeasts. For example, two genes, PaEXG1 and PaEXG2, encoding for exo- $\beta$-glucanases in Pichia anomala $\mathrm{K}$, are responsible for antifungal activity against $B$. cinerea [177]. Finally, proteases are not as well-studied as other microorganisms since they are only produced during the later growth stages [65]. Despite this, some alkaline serine proteases produced by $A$. pullulans PL5 can reduce spore germination and the germ-tube length of $B$. cinerea in vitro [176]. It has also been found that the use of the $\beta-1,3$-glucanaseproducing Cryptococcus laurentii strain LS28 in combination with different antifungals from the benzimidazoles and thiabendazoles family allows postharvest control of the incidence of strains resistant and nonresistant to B. cinerea [178].

\section{Other Mechanisms}

In this review, we summarized antifungal activities that depend on secondary metabolite production. However, there are mechanisms of great interest where microorganisms play major roles (Table 4).

Table 4. Overview of literature reporting the inhibition of Botrytis cinerea by other mechanisms.

\begin{tabular}{|c|c|c|c|c|}
\hline Antifungal Microorganisms & Condition/Plant & Antifungal Metabolite & Antifungal Effect & Reference \\
\hline \multicolumn{5}{|c|}{ Bacteria } \\
\hline $\begin{array}{l}\text { Bacillus amyloliquefaciens } \\
\text { BBC047 }\end{array}$ & Tomato leaves & - & Biofilm formation & [181] \\
\hline Bacillus subtilis FB17 & Tomato plants & - & $\begin{array}{l}\text { Induction of systemic } \\
\text { resistance [ISR] }\end{array}$ & [182] \\
\hline Bacillus velezensis Bvel1 & Arabidopsis thaliana & Azelaic acid & $\begin{array}{l}\text { Induction of systemic } \\
\text { resistance [ISR] }\end{array}$ & [73] \\
\hline Burkholderia phytofirmans PsJN & Grapevines & $\mathrm{H}_{2} \mathrm{O}_{2}$ production & $\begin{array}{l}\text { Induction of systemic } \\
\text { resistance [ISR] }\end{array}$ & [183] \\
\hline Lactobacillus plantarum CM-3 & Strawberry wounds & - & Colonization & [184] \\
\hline Pantoea ananatis BLBT1-08 & Grapevine leaves & - & Colonization & [185] \\
\hline $\begin{array}{l}\text { Pseudomonas aeruginosa 7NSK2, } \\
\text { Pseudomonas fluorescens CHA0, } \\
\text { Pseudomonas aeruginosa 7NSK2, } \\
\text { and Serratia marcescens 90-166 }\end{array}$ & Bean plants & Salicylic acid & $\begin{array}{l}\text { Induction of systemic } \\
\text { resistance [ISR] }\end{array}$ & {$[186,187]$} \\
\hline Pseudomonas syringae L-59-66 & Pear fruits & - & Competition for nutrients & [188] \\
\hline
\end{tabular}


Table 4. Cont.

\begin{tabular}{|c|c|c|c|c|}
\hline Antifungal Microorganisms & Condition/Plant & Antifungal Metabolite & Antifungal Effect & Reference \\
\hline \multicolumn{5}{|c|}{ Fungi } \\
\hline Aureobasidium pullulans L1 & $\begin{array}{l}\text { In vitro and in peach } \\
\text { fruits }\end{array}$ & $\begin{array}{l}\text { Hydroxamate-type } \\
\text { siderophore }\end{array}$ & Iron competition & [105] \\
\hline Gliocladium roseum & Strawberry leaves & - & Nutrient competition & [189] \\
\hline $\begin{array}{l}\text { Trichoderma arundinaceum IBT } \\
40837\end{array}$ & Tomato plants & Trichodiene & $\begin{array}{c}\text { Induction of } \\
\text { defense-related genes }\end{array}$ & [99] \\
\hline $\begin{array}{c}\text { Trichoderma harzianum } \\
\text { Th-LAAO }\end{array}$ & Tobacco leaves & L-amino acid oxidase & $\begin{array}{c}\text { Induction of } \\
\text { defense-related genes }\end{array}$ & [190] \\
\hline $\begin{array}{c}\text { Trichoderma harzianum T39 and } \\
\text { Ulocladium atrum } 385\end{array}$ & Laboratory conditions & - & $\begin{array}{l}\text { Competition for nutrients } \\
\text { and colonization of } \\
\text { necrotic tissue }\end{array}$ & [58] \\
\hline \multicolumn{5}{|c|}{ Yeasts } \\
\hline Pichia angusta ANY-67 & Apple fruit & - & Wound protection & [191] \\
\hline $\begin{array}{l}\text { Rhodotorula glutinis F147 and } \\
\text { Cryptococcus albidus F131 }\end{array}$ & In vitro & - & $\begin{array}{l}\text { Competition for iron, } \\
\text { methionine, leucine, and } \\
\text { other nutrients }\end{array}$ & [192] \\
\hline $\begin{array}{c}\text { Candida saitoana } 240, \text { Candida } \\
\text { oleophila } 182, \text { and } \\
\text { Metschnikowia fructicola NRRL } \\
\text { Y-30752 }\end{array}$ & Fruits & $\begin{array}{l}\text { Overproduction of } \\
\text { reactive oxygen species }\end{array}$ & $\begin{array}{l}\text { Induction of innate } \\
\text { immune responses }\end{array}$ & [65] \\
\hline $\begin{array}{c}\text { Wickerhamomyces anomalus } \\
\text { YE06 }\end{array}$ & Cherry tomatoes & - & $\begin{array}{c}\text { Competition for space and } \\
\text { nutrients }\end{array}$ & [193] \\
\hline
\end{tabular}

\subsection{Competition}

B. cinerea is a necrotrophic pathogen, meaning it obtains organic nutrients from dead cells that it has already killed [194]. In this way, necrotrophic fungi need exogenous nutrients for germination and for growth on plant surfaces in a pre-penetration state [14].

Competition for both nutrients and space is a key factor since colonization is only possible when colonizers can obtain the proper amount of nutrients [89]. Previous studies have shown that non-pathogenic microorganisms are able to colonize plant surfaces, thereby limiting the amount of nutrients available, reducing the pathogen spore germination percentage, and thus reducing the host invasion capacity [103]. Additionally, reduction of the amount of nutrients usually reduces germ-tube growth, reducing infection, necrosis, and expansion of the fungi [58].

Botrytis biocontrol by competition seems to be efficient since conidial germination, germ-tube growth, and complete infection cannot be completed without a sufficient amount of nutrients [192]. Competition seems to be an effective method for postharvest infections by $B$. cinerea as well [38]. Some bacteria have the ability to compete, and as always, Bacillus spp. and Pseudomonas spp. are two of the most important genera when it comes to studying biocontrol. Species such as P. syringae L-59-66, which have antifungal activity mainly because of competition for nutrients [188], and B. amyloliquefaciens BBC047, which is found in tomato leaves where it forms biofilms [181], are good candidates for B. cinerea biocontrol. Other species, like Pantoea ananatis BLBT1-08 and Lactobacillus plantarum CM-3, have been well-studied because they rapidly colonize plant wounds before the establishment of $B$. cinerea, thereby suppressing mycelial growth and disease symptoms [184,185].

Although there are several examples of bacteria that act as competitors, fungi are the most efficient microorganisms for this task since they grow extremely fast, depleting the amount of nutrients available. Two have shown the best results under laboratory and field conditions: T. harzianum T39 and Ulocladium atrum 385 [58]. Moreover, Aureobasidium pullulans L1, which competes for space and amino acids [105], Chlonostachys rosea, Gliocladium catenulatum, T. atroviride, $T$. harzianum, and $U$. novo-zealandiae have already been used for developing commercial fungicides against B. cinerea [4]. For example, G. roseum is a fungus 
that has demonstrated its ability to limit the growth of B. cinerea by limiting the availability of nutrients through competition for their acquisition, either in the phylloplane or in the senescent leaves. [189].

Finally, competition, for both space and nutrients, is considered the main mode of action in yeasts $[65,195]$. Competition for space is not very specific, as it involves the inhibition of fungal growth in general rather than inhibiting the growth of particular species [196]. This is enhanced by the ability to form a biofilm, which confers some advantages, like the wound protection produced by Pichia angusta ANY-67 biofilms, caused by Botrytis infection [191]. Regarding nutrients, yeasts can compete for iron, methionine, leucine, and other nutrients [65] that are needed for several fungal processes, like the germination of fungal spores [195]. Some examples of Botrytis biocontrol, Rhodotorula glutinis F147 and Cryptococcus albidus F131, compete for nutrients that are needed for conidial germination in Botrytis [192]. Some yeasts have also been studied with regard to competition for biocontrol in post-harvest conditions, for example, Wickerhamomyces anomalus YE06, which has been shown to compete with B. cinerea in cherry tomatoes for both space and nutrients [193].

\subsection{Induction of Systemic Resistance}

Plants possess their own defense system that includes physical, chemical, and induced defenses [182]. The latter is defined as "the process of active resistance dependent on the host plant's physical or chemical barriers, activated by biotic or abiotic inducing agents" [186]. This means that its activation depends on some trigger, which can be biotic or abiotic [197]. The pathogen itself may be the trigger that activates this resistance through biochemical reactions or production of pathogenic proteins [103]. For example, during infection, $B$. cinerea produces polygalacturonases, which hydrolyze plant cell wall components, releasing oligogalacturonides that induce a variety of host defense responses [198]. In addition, some non-pathogenic microorganisms can also activate induced resistance [14]. Induced resistance has been shown to be efficient for vegetative tissue biocontrol, and it can be applied locally or systematically [58].

Induced resistance is usually divided in two main groups, systemic acquired resistance (SAR) and inducible systemic resistance (ISR) [182]. The former can be defined as the inherent immunity of the plant, and it is activated either by direct exposure to biotic triggers, both pathogens and non-pathogens, or by abiotic factors, including a number of chemical compounds $[1,199]$. This mechanism mainly depends on the accumulation of pathogenesisrelated proteins and the production of salicylic acid [200], a chemical compound that is usually produced after infection [2]. For example, endophytic microorganisms, such as Pseudomonas aeruginosa 7NSK2, P. fluorescens CHA0, P. aeruginosa 7NSK2, and Serratia marcescens 90-166, produce salicylic acid, which induces resistance against $B$. cinerea in beans and enhances host defense $[186,187]$. Salicylic acid production is also induced by the production of VOCs like trichodiene, produced by T. arundinaceum IBT 40837, which provides plant defense against Botrytis [99]. However, little is known about the resistance against B. cinerea induced by SAR [199].

The latter is similar to a hypersensitive response resulting from the exposure of PGP microorganisms [200]. Here, ethylene and jasmonic acid are the two phytohormones that induce the response [2]. Both rhizobacteria and bacterial endophytes have been demonstrated to induce ISR. For example, Burkholderia phytofirmans PsJN, a plant endophyte, induces accumulation of phenolic compounds and strengthens the plant during the colonization of cell walls in the exodermis against $B$. cinerea on grapevines [183]. In the same way, B. subtilis FB17 can induce ISR in plants via stimulation of the jasmonic and ethylene pathways [182]. There are also studies on the specific bacterial metabolites that induce ISR. In this sense, B. velezensis Bvel1 produces azelaic acid, which triggers the host immune response in A. thaliana [73]. Fungi like Trichoderma have also been studied for their ability to induce ISR. Thus, $T$. harzianum in tobacco confers resistance to $B$. cinerea through the expression of L-amino acid oxidase since this enzyme activates the expression 
of defense-related genes and genes involved in salicylic acid, jasmonic acid, and ethylene biosynthesis [201]. Molecules produced by Trichoderma, such as Th-LAAO, have also been studied because they activate plant defense mechanisms, contributing to the ISR of the host against $B$. cinerea [190]. Finally, some yeasts are also related to the induction of resistance. For example, Candida saitoana 240, C. oleophila 182, and Metschnikowia NRRL Y-30752 enhance the innate immune response in plants, increasing pathogen resistance [65].

\section{Conclusions}

Fungi, specifically B. cinerea, are some of the main threats to the agriculture industry. They are not only responsible for $40 \%$ of crop losses worldwide but also for economic losses of USD 10 to 100 billion. Until now, chemical pesticides have been the most useful solution to this problem; however, they come with negative environmental consequences that are now rejected by the population. This, together with the specter of resistance, has led to the suggestion that a more sustainable and safer alternative is needed. In this respect, biopesticides have been studied for the last few years, and they were proven to be an innovative solution. Their potential lies in the use of PGP microorganisms, which are known to possess different plant growth promotion and fungal biocontrol mechanisms, providing a wide variety of new sources for the development of biopesticides. The wide diversity of microorganisms and microbial metabolisms has revealed a great number of modes of action with antifungal potential. In this review, we highlighted some of the most studied mechanisms. One of the most studied is the production of secondary metabolites, where siderophores (e.g., pyoverdine, enterochelin, bacillibactin), lytic enzymes (e.g., chitinase, endoglucanase, protease), antibiotic substances (e.g., surfactin, fengycin, gliotoxin), and volatile organic compounds (VOCs) (e.g., benzothiazole, trichodermol, 3-methyl-1-butanol) are included. Their production depends on the type of microorganism involved, but we can confirm some genera that are outlined among the others, such as Bacillus, Pseudomonas, and Trichoderma. They produce a great variability of secondary metabolites with antifungal activity, like cyclic lipopeptides in Bacillus, siderophores in Pseudomonas, and lytic enzymes in Trichoderma.

Additionally, other mechanisms have been classified as protection mechanisms, with competition and induction of systemic resistance being the most important, and other microorganisms have also been studied in recent years, for example, Metschnikowia pulcherrima and Serratia plymuthica.

Although their effectiveness in vitro has been tested against several phytopathogens, including $B$. cinerea, further research needs to be done in order to elucidate how they work and what their effects are when applied in the field. Fortunately, the wide diversity of molecules resulting from the wide diversity of microbial metabolisms is a powerful weapon in the fight against plant fungal diseases since it may affect different targets in the Botrytis life cycle and structure. Some of the most studied have already been tested, and they are currently being used in the agriculture industry with satisfactory results.

Author Contributions: Conceptualization, J.D.F.-F. and R.R.; methodology, R.R.-C.; investigation, R.R.-C. and J.D.F.-F.; data curation, R.R.; writing—original draft preparation, R.R.-C.; writing—review and editing, J.D.F.-F. and R.R.; supervision, R.R.; funding acquisition, R.R. All authors have read and agreed to the published version of the manuscript.

Funding: This research was funded by RETOS 2017 BOTRYBIOC RTC-2017-6007-2 granted by Ministerio de Ciencia Innovación y Universidades from Spain; J.D.F.-F. is currently a recipient of the post-doctoral Marie Skłodowska-Curie Fellowship No. 101003373.

Institutional Review Board Statement: Not applicable.

Informed Consent Statement: Not applicable.

Acknowledgments: The authors also thank the Excellence Unit of the Spanish-Portuguese Institute for Agricultural Research (CIALE) (CLU-2018-04) for the provision of research facilities.

Conflicts of Interest: The authors declare no conflict of interest. 


\section{References}

1. Lazarovits, G.; Turnbull, A.; Johnston-Monje, D. Plant Health Management: Biological Control of Plant Pathogens. In Encyclopedia of Agriculture and Food Systems; Elsevier Ltd.: London, UK, 2014; pp. 388-399.

2. Timothy, O.; Adejumo, R.T. Biopesticides: Botanicals and Microorganisms for Improving Agriculture and Human Health; Ed. LogosVerlag Berlin: Berlin, Germany, 2021; pp. 106-111.

3. Fisher, M.C.; Henk, D.A.; Briggs, C.J.; Brownstein, J.S.; Madoff, L.C.; McCraw, S.L.; Gurr, S.J. Emerging fungal threats to animal, plant and ecosystem health. Nature 2012, 484, 186-194. [CrossRef] [PubMed]

4. Bolívar-Anillo, H.J.; Garrido, C.; Collado, I.G. Endophytic microorganisms for biocontrol of the phytopathogenic fungus Botrytis cinerea. Phytochem. Rev. 2020, 19, 721-740. [CrossRef]

5. Doehlemann, G.; Ökmen, B.; Zhu, W.; Sharon, A. Plant Pathogenic Fungi. In The Fungal Kingdom; American Society of Microbiology, Ed.; Wiley: Hoboken, NJ, USA, 2017; pp. 703-726.

6. Rodriguez-Moreno, L.; Ebert, M.K.; Bolton, M.D.; Thomma, B.H. Tools of the crook-infection strategies of fungal plant pathogens. Plant J. 2018, 93, 664-674. [CrossRef] [PubMed]

7. Cordero-Bueso, G.; Mangieri, N.; Maghradze, D.; Foschino, R.; Valdetara, F.; Cantoral, J.M.; Vigentini, I. Wild Grape-Associated Yeasts as Promising Biocontrol Agents against Vitis vinifera Fungal Pathogens. Front. Microbiol. 2017, 8, 2025. [CrossRef] [PubMed]

8. Casadevall, A. Determinants of virulence in the pathogenic fungi. Fungal Biol. Rev. 2007, 21, 130-132. [CrossRef]

9. Taylor, T.N.; Krings, M.; Taylor, E.L. Fungal Spores. In Fossil Fungi; Elsevier: London, UK, 2015; pp. $221-238$.

10. Hua, L.; Yong, C.; Zhanquan, Z.; Boqiang, L.; Guozheng, Q.; Shiping, T. Pathogenic mechanisms and control strategies of Botrytis cinerea causing post-harvest decay in fruits and vegetables. Food Qual. Saf. 2018, 2, 111-119. [CrossRef]

11. Dean, R.; Van Kan, J.A.; Pretorius, Z.A.; Hammond-Kosack, K.E.; Di Pietro, A.; Spanu, P.D.; Rudd, J.J.; Dickman, M.; Kahmann, R.; Ellis, J.; et al. The Top 10 fungal pathogens in molecular plant pathology. Mol. Plant Pathol. 2012, 13, 414-430. [CrossRef]

12. Shaw, M.W.; Emmanuel, C.J.; Emilda, D.; Terhem, R.B.; Shafia, A.; Tsamaidi, D.; Emblow, M.; van Kan, J.A. Analysis of Cryptic, Systemic Botrytis Infections in Symptomless Hosts. Front. Plant Sci. 2016, 7, 625. [CrossRef]

13. Pinedo, C.; Moraga, J.; Collado, I.G.; Aleu, J. Botrytis species as biocatalysts. Phytochem. Rev. 2020, 19, 529-558. [CrossRef]

14. Elad, Y. Mechanisms involved in the biological control of Botrytis cinerea incited diseases. Eur. J. Plant Pathol. 1996, 102, 719-732. [CrossRef]

15. Williamson, B.; Tudzynski, B.; Tudzynski, P.; Van Kan, J.A. Botrytis cinerea: The cause of grey mould disease. Mol. Plant Pathol. 2007, 8, 561-580. [CrossRef] [PubMed]

16. Wang, X.; Glawe, D.A.; Kramer, E.; Weller, D.; Okubara, A. Biological Control of Botrytis cinerea: Interactions with Native Vineyard Yeasts from Washington State. Phytopathology 2018, 108, 691-701. [CrossRef] [PubMed]

17. Shi, J.F.; Sun, C.Q. Isolation, identification, and biocontrol of antagonistic bacterium against Botrytis cinerea after tomato harvest. Braz. J. Microbiol. 2017, 48, 706-714. [CrossRef] [PubMed]

18. Plesken, C.; Pattar, P.; Reiss, B.; Noor, Z.N.; Zhang, L.; Klug, K.; Huettel, B.; Hahn, M. Genetic Diversity of Botrytis cinerea Revealed by Multilocus Sequencing, and Identification of B. cinerea Populations Showing Genetic Isolation and Distinct Host Adaptation. Front. Plant Sci. 2021, 12, 663027. [CrossRef]

19. Chen, P.H.; Chen, R.Y.; Chou, J.Y. Screening and evaluation of yeast antagonists for biological control of Botrytis cinerea on strawberry fruits. Mycobiology 2018, 46, 33-46. [CrossRef]

20. González-Domínguez, E.; Caffi, T.; Ciliberti, N.; Rossi, V. A mechanistic model of botrytis cinerea on grapevines that includes weather, vine growth stage, and the main infection pathways. PLoS ONE 2015, 10, e0140444. [CrossRef]

21. Elmer, A.G.; Michailides, T.J. Epidemiology of Botrytis cinerea in Orchard and Vine Crops. In Botrytis: Biology, Pathology and Control; Springer: Dordrecht, The Netherlands, 2007; pp. 243-272.

22. Van Kan, J.A. Infection Strategies of Botrytis cinerea. Acta Hortic. 2005, 669, 77-90. [CrossRef]

23. Doss, R.; Potter, S.W.; Chastagner, G.A.; Christian, J.K. Adhesion of Nongerminated Botrytis cinerea Conidia to Several Substrata. Appl. Environ. Microbiol. 1993, 59, 1786-1791. [CrossRef]

24. Cole, G.T. Basic Biology of Fungi. In Medical Microbiology, 4th ed.; University of Texas Medical Branch at Galveston: Galveston, TX, USA, 1996.

25. Williamson, B.; Duncan, G.H.; Harrison, J.G.; Harding, L.A.; Elad, Y.; Zimand, G. Effect of humidity on infection of rose petals by dry-inoculated conidia of Botrytis cinerea. Mycol. Res. 1995, 99, 1303-1310. [CrossRef]

26. Harper, A.M.; Strange, R.N.; Langcake, P. Characterization of the nutrients required by Botrytis cinerea to infect broad bean leaves. Physiol. Plant Pathol. 1981, 19, 153-167. [CrossRef]

27. Elad, Y.; Volpin, H. The involvement of ethylene and calcium in gray mold of pelargonium, ruscus, and rose plants. Phytoparasitiea 1988, 16, 119-131. [CrossRef]

28. McNicol, R.J.; Williamson, B.; Young, K. Ethylene production by black currant flowers infected by Botrytis cinerea. Acta Hortic. 1989, 262, 209-216. [CrossRef]

29. Wojtaszek, P. Oxidative burst: An early plant response to pathogen infection. Biochem. J. 1997, 322, 681-692. [CrossRef]

30. Rebordinos, L.; Cantoral, J.M.; Prieto, M.V.; Hanson, J.R.; Collado, I.G. The phytotoxic activity of some metabolites of Botrytis cinerea. Phytochemistry 1996, 42, 383-387. [CrossRef]

31. Tiedemann, A.V. Evidence for a primary role of active oxygen species in induction of host cell death during infection of bean leaves with Botrytis cinerea. Physiol. Mol. Plant Pathol. 1997, 50, 151-166. [CrossRef] 
32. Ten Have, A.; Tenberge, K.B.; Benen, J.A.; Tudzynski, P.; Visser, J.; van Kan, J.A. The Contribution of Cell Wall Degrading Enzymes to Pathogenesis of Fungal Plant Pathogens. In Agricultural Applications; Springer: Berlin/Heidelberg, Germany, 2002; pp. 341-358.

33. Lian, Q.; Zhang, J.; Gan, L.; Ma, Q.; Zong, Z.; Wang, Y. The biocontrol efficacy of Streptomyces pratensis LMM15 on Botrytis cinerea in Tomato. Biomed. Res. Int. 2017, 2017, 9486794. [CrossRef]

34. Kim, Y.C.; Hur, J.Y.; Park, S.K. Biocontrol of Botrytis cinerea by chitin-based cultures of Paenibacillus elgii HOA73. Eur. J. Plant Pathol. 2019, 155, 253-263. [CrossRef]

35. Jiao, X.; Takishita, Y.; Zhou, G.; Smith, D.L. Plant Associated Rhizobacteria for Biocontrol and Plant Growth Enhancement. Front. Plant Sci. 2021, 12, 17. [CrossRef]

36. Leroch, M.; Plesken, C.; Weber, R.W.; Kauff, F.; Scalliet, G.; Hahn, M. Gray mold populations in German strawberry fields are resistant to multiple fungicides and dominated by a novel clade closely related to Botrytis cinerea. Appl. Environ. Microbiol. 2013, 79, 159-167. [CrossRef]

37. Pertot, I.; Giovannini, O.; Benanchi, M.; Caffi, T.; Rossi, V.; Mugnai, L. Combining biocontrol agents with different mechanisms of action in a strategy to control Botrytis cinerea on grapevine. Crop Prot. 2017, 97, 85-93. [CrossRef]

38. Haidar, R.; Fermaud, M.; Calvo-Garrido, C.; Roudet, J.; Deschamps, A. Modes of action for biological control of Botrytis cinerea by antagonistic bacteria. Phytopathol. Mediterr. 2017, 55, 301-322.

39. Damalas, C.A.; Koutroubas, S.D. Current Status and Recent Developments in Biopesticide Use. Agriculture 2018, 8, 13. [CrossRef]

40. Chandler, D.; Bailey, A.S.; Tatchell, G.M.; Davidson, G.; Greaves, J.; Grant, W.P. The development, regulation and use of biopesticides for integrated pest management. Philos. Trans. R. Soc. B Biol. Sci. 2011, 366, 1987-1998. [CrossRef] [PubMed]

41. Schalchli, H.; Tortella, G.R.; Rubilar, O.; Parra, L.; Hormazabal, E.; Quiroz, A. Fungal volatiles: An environmentally friendly tool to control pathogenic microorganisms in plants. Crit. Rev. Biotechnol. 2016, 36, 144-152. [CrossRef]

42. Ons, L.; Bylemans, D.; Thevissen, K.; Cammue, B.P. Combining Biocontrol Agents with Chemical Fungicides for Integrated Plant Fungal Disease Control. Microorganisms 2020, 8, 1930. [CrossRef]

43. Hahn, M. The rising threat of fungicide resistance in plant pathogenic fungi: Botrytis as a case study. J. Chem. Biol. 2014, 7, 133-141. [CrossRef]

44. Fan, F.; Hamada, M.S.; Li, N.; Li, G.Q.; Luo, C.X. Multiple fungicide resistance in Botrytis cinerea from greenhouse strawberries in Hubei Province, China. Plant Dis. 2017, 101, 601-606. [CrossRef]

45. Schmidt, J.E.; Gaudin, A.C. What is the agronomic potential of biofertilizers for maize? A meta-analysis. FEMS Microbiol. Ecol. 2018, 94, fiy094. [CrossRef]

46. Umesha, S.; Singh, K.; Singh, R. Microbial Biotechnology and Sustainable Agriculture. In Biotechnology for Sustainable Agriculture: Emerging Approaches and Strategies; Elsevier: London, UK, 2017; pp. 185-205.

47. Compant, S.; Duffy, B.; Nowak, J.; Clément, C.; Barka, E.A. Use of plant growth-promoting bacteria for biocontrol of plant diseases: Principles, mechanisms of action, and future prospects. Appl. Environ. Microbiol. Am. Soc. Microbiol. ASM 2005, 71, 4951-4959. [CrossRef]

48. Khan, A.L.; Waqas, M.; Kang, S.M.; Al-Harrasi, A.; Hussain, J.; Al-Rawahi, A.; Al-Khiziri, S.; Ullah, I.; Ali, L.; Jung, H.Y.; et al. Bacterial endophyte Sphingomonas sp. LK11 produces gibberellins and IAA and promotes tomato plant growth. J. Microbiol. 2014, 52, 689-695. [CrossRef]

49. Nair, D.N.; Padmavathy, S. Impact of endophytic microorganisms on plants, environment and humans. Sci. World J. 2014, 2014, 250693. [CrossRef]

50. Beneduzi, A.; Ambrosini, A.; Passaglia, L.M. Plant growth-promoting rhizobacteria [PGPR]: Their potential as antagonists and biocontrol agents. Genet. Mol. Biol. Soc. Bras. Genética 2012, 35, 1044-1051. [CrossRef]

51. De Silva, N.I.; Brooks, S.; Lumyong, S.; Hyde, K.D. Use of endophytes as biocontrol agents. Fungal Biol. Rev. 2019, 33, 133-148. [CrossRef]

52. Vellasamy, S.; Hariharan, H. Controlling Strategies (Diagnosis/Quarantine/Eradication) of Plant Pathogenic Bacteria. Sustain. Approaches Control Plant Pathog. Bact. 2015, 98-127.

53. Jiang, C.H.; Liao, M.J.; Wang, H.K.; Zheng, M.Z.; Xu, J.J.; Guo, J.H. Bacillus velezensis, a potential and efficient biocontrol agent in control of pepper gray mold caused by Botrytis cinerea. Biol. Control. 2018, 126, 147-157. [CrossRef]

54. Kasfi, K.; Taheri, P.; Jafarpour, B.; Tarighi, S. Identification of epiphytic yeasts and bacteria with potential for biocontrol of grey mold disease on table grapes caused by Botrytis cinerea. Span. J. Agric. Res. 2018, 16, 1002. [CrossRef]

55. Sansinenea, E.; Ortiz, A. Secondary metabolites of soil Bacillus spp. Biotechnol. Lett. 2011, 33, 1523-1538. [CrossRef]

56. Toral, L.; Rodríguez, M.; Béjar, V.; Sampedro, I. Antifungal Activity of Lipopeptides from Bacillus XT1 CECT 8661 against Botrytis cinerea. Front. Microbiol. 2018, 9, 1315. [CrossRef]

57. Raaijmakers, J.M.; De Bruijn, I.; Nybroe, O.; Ongena, M. Natural functions of lipopeptides from Bacillus and Pseudomonas: More than surfactants and antibiotics. FEMS Microbiol. Rev. 2010, 34, 1037-1062. [CrossRef]

58. Elad, Y.; Williamson, B.; Tudzynski, P.; Delen, N. Botrytis: Biology, Pathology and Control; Springer Science \& Business Media: Germany, Berlin/Heidelberg, 2004; pp. 1-403.

59. Wang, X.; Zhou, X.; Cai, Z.; Guo, L.; Chen, X.; Chen, X.; Liu, J.; Feng, M.; Qiu, Y.; Zhang, Y.; et al. A biocontrol strain of Pseudomonas aeruginosa CQ-40 promote growth and control Botrytis cinerea in tomato. Pathogens 2021, 10, 22. [CrossRef]

60. Ash, C.; Priest, F.G.; Collins, M.D. Molecular identification of rRNA group 3 bacilli [Ash, Farrow, Wallbanks and Collins] using a PCR probe test. Antonie Leeuwenhoek 1993, 64, 253-260. [CrossRef] [PubMed] 
61. Thambugala, K.M.; Daranagama, D.A.; Phillips, A.J.; Kannangara, S.D.; Promputtha, I. Fungi vs. Fungi in Biocontrol: An Overview of Fungal Antagonists Applied against Fungal Plant Pathogens. Front. Cell. Infect. Microbiol. 2020, 10, 718. [CrossRef] [PubMed]

62. Liu, J.; Sui, Y.; Wisniewski, M.; Droby, S.; Liu, Y. Review: Utilization of antagonistic yeasts to manage postharvest fungal diseases of fruit. Int. J. Food Microbiol. 2013, 167, 153-160. [CrossRef] [PubMed]

63. Parafati, L.; Vitale, A.; Polizzi, G.; Restuccia, C.; Cirvilleri, G. Understanding the mechanism of biological control of postharvest phytopathogenic moulds promoted by food isolated yeasts. Acta Hortic. 2016, 1144, 93-100. [CrossRef]

64. Saravanakumar, D.; Ciavorella, A.; Spadaro, D.; Garibaldi, A.; Gullino, M.L. Metschnikowia pulcherrima strain MACH1 outcompetes Botrytis cinerea, Alternaria alternata and Penicillium expansum in apples through iron depletion. Postharvest Biol. Technol. 2008, 49, 121-128. [CrossRef]

65. Freimoser, F.M.; Rueda-Mejia, M.; Tilocca, B.; Migheli, Q. Biocontrol yeasts: Mechanisms and applications. World J. Microbiol. Biotechnol. 2019, 35, 154. [CrossRef]

66. Jijakli, M.H.; Lepoivre, P. Characterization of an exo- $\beta-1,3-$ glucanase produced by Pichia anomala strain K, antagonist of Botrytis cinerea on apples. Phytopathology 1998, 88, 335-343. [CrossRef]

67. Masih, E.I.; Alie, I.; Paul, B. Can the grey mould disease of the grape-vine be controlled by yeast? FEMS Microbiol. Lett. 2000, 189, 233-237. [CrossRef]

68. Leroux, P. Chemical control of Botrytis and Its Resistance To Chemical Fungicides. In Botrytis: Biology, Pathology and Control; Springer: Dordrecht, The Netherlands, 2007; pp. 195-222.

69. Lim, S.M.; Yoon, M.Y.; Choi, G.J.; Choi, Y.H.; Jang, K.S.; Shin, T.S.; Park, H.W.; Yu, N.H.; Kim, Y.H.; Kim, J.C. Diffusible and volatile antifungal compounds produced by an antagonistic Bacillus velezensis G341 against various phytopathogenic fungi. Plant Pathol. J. 2017, 33, 488-498. [CrossRef]

70. Zhang, X.; Song, C.; Bai, Y.; Hu, J.; Pan, H. Cytotoxic and antimicrobial activities of secondary metabolites isolated from the deep-sea-derived Actinoalloteichus cyanogriseus 12A22. 3 Biotech 2021, 11, 283. [CrossRef]

71. Barka, E.A.; Belarbi, A.; Hachet, C.; Nowak, J.; Audran, J.C. Enhancement of in vitro growth and resistance to gray mould of Vitis vinifera co-cultured with plant growth-promoting rhizobacteria. FEMS Microbiol. Lett. 2000, 186, 91-95. [CrossRef]

72. Su, Z.; Chen, X.; Liu, X.; Guo, Q.; Li, S.; Lu, X.; Zhang, X.; Wang, P.; Dong, L.; Zhao, W.; et al. Genome mining and UHPLC-QTOFMS/MS to identify the potential antimicrobial compounds and determine the specificity of biosynthetic gene clusters in Bacillus subtilis NCD-2. BMC Genom. 2020, 21, 767.

73. Nifakos, K.; Tsalgatidou, C.; Thomloudi, E.E.; Skagia, A.; Kotopoulis, D.; Baira, E.; Delis, C.; Papadimitriou, K.; Markellou, E.; Venieraki, A.; et al. Genomic Analysis and Secondary Metabolites Production of the Endophytic Bacillus velezensis Bvel1: A Biocontrol Agent against Botrytis cinerea Causing Bunch Rot in Post-Harvest Table Grapes. Plants 2021, 10, 1716. [CrossRef]

74. Lambrese, Y.; Guiñez, M.; Calvente, V.; Sansone, G.; Cerutti, S.; Raba, J.; Sanz Ferramola, M.I. Production of siderophores by the bacterium Kosakonia radicincitans and its application to control of phytopathogenic fungi. Bioresour. Technol. Rep. 2018, 3, 82-87. [CrossRef]

75. Priyanka, R.; Nakkeeran, S. Ochrobactrum ciceri mediated induction of defence genes and antifungal metabolites enhance the biocontrol efficacy for the management of Botrytis leaf blight of Lilium under protected conditions. J. Plant Pathol. 2019, 101, 323-337. [CrossRef]

76. De Moura, G.G.; de Barros, A.V.; Machado, F.; Martins, A.D.; da Silva, C.M.; Durango, L.G.; Forim, M.; Alves, E.; Pasqual, M.; Doriad, J. Endophytic bacteria from strawberry plants control gray mold in fruits via production of antifungal compounds against Botrytis cinerea L. Microbiol. Res. 2021, 251, 126793. [CrossRef]

77. Aznar, A.; Dellagi, A. New insights into the role of siderophores as triggers of plant immunity: What can we learn from animals? J. Exp. Bot. 2015, 66, 3001-3010. [CrossRef]

78. Haggag, W.M.; Abo, M.; Soud, E. Production and Optimization of Pseudomonas fluorescens Biomass and Metabolites for Biocontrol of Strawberry Grey Mould. Am. J. Plant Sci. 2012, 3, 836-845. [CrossRef]

79. Sansone, G.; Rezza, I.; Fernández, G.; Calvente, V.; Benuzzi, D.; Sanz, M.I. Inhibitors of polygalacturonase and laccase of Botrytis cinerea and their application to the control of this fungus. Int. Biodeterior. Biodegradation. 2011, 65, 243-247. [CrossRef]

80. De Cesare, G.B.; Cristy, S.A.; Garsin, D.A.; Lorenz, M.C. Antimicrobial peptides: A new frontier in antifungal therapy. MBio. 2020, 11, e02123-20.

81. Coleman, J.J.; Ghosh, S.; Okoli, I.; Mylonakis, E. Antifungal activity of microbial secondary metabolites. PLoS ONE 2011, 6, 25321. [CrossRef]

82. Di Pietro, A. Endochitinase from Gliocladium virens: Isolation, Characterization, and Synergistic Antifungal Activity in Combination with Gliotoxin. Phytopathology 1993, 83, 308. [CrossRef]

83. Brunner, K.; Zeilinger, S.; Ciliento, R.; Woo, S.L.; Lorito, M.; Kubicek, C.; Mach, R.L. Improvement of the Fungal Biocontrol Agent Trichoderma atroviride To Enhance both Antagonism and Induction of Plant Systemic Disease Resistance. Appl. Environ. Microbiol. 2005, 71, 3959. [CrossRef]

84. Marín-Chacón, M.A.; Rivera-Coto, G.; Villalobos-Moya, K.; Orozco-Rodríguez, R.; Orozco-Cayasso, S. Evaluation of Botrytis cinerea Pers., antagonist fungi in blackberry plantations of Costa Rica. Agron. Costarric. 2017, 41, 7-18.

85. Prasongsuk, S.; Lotrakul, P.; Ali, I.; Bankeeree, W.; Punnapayak, H. The current status of Aureobasidium pullulans in biotechnology. Folia Microbiol. 2018, 63, 129-140. [CrossRef] 
86. Santos, A.; Sánchez, A.; Marquina, D. Yeasts as biological agents to control Botrytis cinerea. Microbiol. Res. 2004, 159, 331-338. [CrossRef]

87. Sansone, G.; Rezza, I.; Calvente, V.; Benuzzi, D.; Sanz De Tosetti, M.I. Control of Botrytis cinerea strains resistant to iprodione in apple with rhodotorulic acid and yeasts. Postharvest. Biol. Technol. 2005, 35, 245-251. [CrossRef]

88. Belda, I.; Ruiz, J.; Alonso, A.; Marquina, D.; Santos, A. The Biology of Pichia membranifaciens Killer Toxins. Toxins 2017, 9,112 [CrossRef]

89. Heydari, A.; Pessarakli, M. A review on biological control of fungal plant pathogens using microbial antagonists. J. Biol. Sci. 2010, 10, 273-290. [CrossRef]

90. Nagórska, K.; Bikowski, M.; Obuchowski, M. Multicellular behaviour and production of a wide variety of toxic substances support usage of Bacillus subtilis as a powerful biocontrol agent. Acta Biochim. Pol. 2007, 54, 495-508. [CrossRef]

91. Stein, T. Bacillus subtilis antibiotics: Structures, syntheses and specific functions. Mol. Microbiol. 2005, 56, 845-857. [CrossRef] [PubMed]

92. Lin, F.; Huang, Z.; Chen, Y.; Zhou, L.; Chen, M.; Sun, J.; Lu, Z.; Lu, Y. Effect of combined Bacillomycin D and chitosan on growth of Rhizopus stolonifer and Botrytis cinerea and cherry tomato preservation. J. Sci. Food Agric. 2021, 101, 229-239. [CrossRef] [PubMed]

93. Borriss, R. Bacillus, a Plant-Beneficial Bacterium. In Principles of Plant-Microbe Interactions; Springer: Cham, Switzerland, 2015; pp. 379-391.

94. Henry, G.; Deleu, M.; Jourdan, E.; Thonart, P.; Ongena, M. The bacterial lipopeptide surfactin targets the lipid fraction of the plant plasma membrane to trigger immune-related defence responses. Cell Microbiol. 2011, 13, 1824-1837. [CrossRef]

95. Souto, G.I.; Correa, O.S.; Montecchia, M.S.; Kerber, N.L.; Pucheu, N.L.; Bachur, M.; García, A.F. Genetic and functional characterization of a Bacillus s strain excreting surfactin and antifungal metabolites partially identified as iturin-like compounds. J. Appl. Microbiol. 2004, 97, 1247-1256. [CrossRef]

96. Chitarra, G.S.; Breeuwer, P.; Nout, M.J.; van Aelst, A.C.; Rombouts, F.M.; Abee, T. An antifungal compound produced by Bacillus subtilis YM 10-20 inhibits germination of Penicillium roqueforti conidiospores. J. Appl. Microbiol. 2003, 94, 159-166. [CrossRef]

97. Hu, F.; Liu, Y.; Li, S. Rational strain improvement for surfactin production: Enhancing the yield and generating novel structures. Microb. Cell Factories 2019, 18, 42. [CrossRef]

98. Nakkeeran, S.; Priyanka, R.; Rajamanickam, S.; Sivakumar, U. Bacillus amyloliquefaciens alters the diversity of volatile and non-volatile metabolites and induces the expression of defence genes for the management of Botrytis leaf blight of Lilium under protected conditions. J. Plant Pathol. 2020, 102, 1179-1189. [CrossRef]

99. Mengistu, A.A. Endophytes: Colonization, Behaviour, and Their Role in Defense Mechanism. Int. J. Microbiol. 2020, $2020,6927219$. [CrossRef]

100. Ait Barka, E.; Gognies, S.; Nowak, J.; Audran, J.C.; Belarbi, A. Inhibitory effect of endophyte bacteria on Botrytis cinerea and its influence to promote the grapevine growth. Biol. Control. 2002, 24, 135-142. [CrossRef]

101. Tapwal, A.; Singh, U.; Teixeira, J.A.; Singh, G.; Garg, S.; Kumar, R. In Vitro Antagonism of Trichoderma viride against Five Phytopathogens. Pest Technol. 2011, 5, 59-62.

102. Tiwari, S.; Prasad, V.; Lata, C. Bacillus: Plant Growth Promoting Bacteria For Sustainable Agriculture and Environment. In New and Future Developments in Microbial Biotechnology and Bioengineering: Microbial Biotechnology in Agro-Environmental Sustainability; Elsevier: London, UK, 2019; pp. 43-55.

103. Carmona-Hernandez, S.; Reyes-Pérez, J.J.; Chiquito-Contreras, R.G.; Rincon-Enriquez, G.; Cerdan-Cabrera, C.R.; HernandezMontiel, L.G. Biocontrol of postharvest fruit fungal diseases by bacterial antagonists: A review. Agronomy 2019, 9, 121. [CrossRef]

104. Page, M.G. The Role of Iron and Siderophores in Infection, and the Development of Siderophore Antibiotics. Clin. Infect. Dis. 2019, 69, 529-537. [CrossRef]

105. Di Francesco, A.; Baraldi, E. How siderophore production can influence the biocontrol activity of Aureobasidium pullulans against Monilinia laxa on peaches. Biol. Control. 2021, 152, 104456. [CrossRef]

106. Shanmugaiah, V.; Nithya, K.; Harikrishnan, H.; Jayaprakashvel, M.; Balasubramanian, N. Biocontrol Mechanisms of Siderophores against Bacterial Plant Pathogens. In Sustainable Approaches to Controlling Plant Pathogenic Bacteria; CRC Press: Boca Raton, USA, 2015; pp. 167-190.

107. Oleńska, E.; Małek, W.; Wójcik, M.; Swiecicka, I.; Thijs, S.; Vangronsveld, J. Beneficial features of plant growth-promoting rhizobacteria for improving plant growth and health in challenging conditions: A methodical review. Sci. Total Environ. 2020, 743, 140682. [CrossRef]

108. Crowley, D.E. Microbial Siderophores in the Plant Rhizosphere. In Iron Nutrition in Plants and Rhizospheric Microorganisms; Springer: Dordrecht, The Netherlands, 2006; pp. 169-198.

109. Höfte, M. Classes of Microbial Siderophores. In Iron Chelation Plants Soil Microorg; Acad Press: New York, NY, USA, 1992; pp. 3-26.

110. Crosa, J.H.; Walsh, C.T. Genetics and assembly line enzymology of siderophore biosynthesis in bacteria. Microbiol. Mol. Biol. Rev. 2002, 66, 223-249. [CrossRef]

111. Saha, M.; Sarkar, S.; Sarkar, B.; Sharma, B.K.; Bhattacharjee, S.; Tribedi, P. Microbial siderophores and their potential applications: A review. Environ. Sci. Pollut. Res. Int. 2016, 23, 3984-3999. [CrossRef]

112. Renshaw, J.C.; Robson, G.D.; Trinci, A.J.; Wiebe, M.G.; Livens, F.R.; Collison, D.; Taylor, R.J. Fungal siderophores: Structures, functions and applications. Mycol. Res. 2002, 106, 1123-1142. [CrossRef] 
113. Winkelmann, G. Structural and stereochemical aspects of iron transport in fungi. Biotechnol. Adv. 1990, 8, 207-231. [CrossRef]

114. Welzel, K.; Eisfeld, K.; Antelo, L.; Anke, T.; Anke, H. Characterization of the ferrichrome A biosynthetic gene cluster in the homobasidiomycete Omphalotus olearius. FEMS Microbiol. Lett. 2005, 249, 157-163. [CrossRef] [PubMed]

115. Jalal, M.A.; Galles, J.L.; Van der Helm, D. Structure of des[diserylglycyl]ferrirhodin, DDF, a novel siderophore from Aspergillus ochraceous. J. Org. Chem. 2002, 50, 5642-5645. [CrossRef]

116. Calvente, V.; Benuzzi, D.; De Tosetti, M.I. Antagonistic action of siderophores from Rhodotorula glutinis upon the postharvest pathogen Penicillium expansum. Int. Biodeterior. Biodegrad. 1999, 43, 167-172. [CrossRef]

117. Choi, G.J.; Kim, J.C.; Jang, K.S.; Nam, M.H.; Lee, S.W.; Kim, H.T. Biocontrol activity of Acremonium strictum BCP against Botrytis diseases. Plant Pathol. J. 2009, 25, 165-171. [CrossRef]

118. Khan, M.S.; Gao, J.; Munir, I.; Zhang, M.; Liu, Y.; Moe, T.S.; Xue, J.; Zhang, X. Characterization of Endophytic Fungi, Acremonium s, from Lilium davidii and Analysis of Its Antifungal and Plant Growth-Promoting Effects. Biomed. Res. Int. 2021, 2021, 9930210. [CrossRef] [PubMed]

119. Ferramola, M.; Benuzzi, D.; Calvente, V.; Sansone, G.; Cerutti, S.; Raba, J. The Use of Siderophores for Improving the Control Of Postharvest Diseases In Stored Fruits And Vegetables. In Microbial Pathogens and Strategies for Combating Them: Science, Technology and Education; Formatex Research Center: Badajoz, Spain, 2013.

120. Sipiczki, M. Metschnikowia strains isolated from botrytized grapes antagonize fungal and bacterial growth by iron depletion. Appl. Environ. Microbiol. 2006, 72, 6716-6724. [CrossRef]

121. Sipiczki, M. Metschnikowia pulcherrima and related pulcherrimin-producing yeasts: Fuzzy species boundaries and complex antimicrobial antagonism. Microorganisms 2020, 8, 1029. [CrossRef]

122. Dave, B.; Kena Anshuman, H. Siderophores of halophilic archaea and their chemical characterization. Indian J. Exp. Biol. 2006, 44, 340-344.

123. Payne, S.M.; Niesel, D.W.; Peixotto, S.S.; Lawlor, K.M. Expression of Hydroxamate and Phenolate Siderophores by Shigella flexneri. J. Bacteriol. 1983, 155, 949-955. [CrossRef]

124. Dertz, E.A.; Stintzi, A.; Raymond, K.N. Siderophore-mediated iron transport in Bacillus subtilis and Corynebacterium glutamicum. JBIC J. Biol. Inorg. Chem. 2006, 11, 1087-1097. [CrossRef]

125. Pal, K.K.; Tilak, K.V.; Saxena, A.K.; Dey, R.; Singh, C.S. Suppression of maize root diseases caused by Macrophomina phaseolina, Fusarium moniliforme and Fusarium graminearum by plant growth promoting rhizobacteria. Microbiol. Res. 2001, 156, 209-223. [CrossRef]

126. Yu, X.; Ai, C.; Xin, L.; Zhou, G. The siderophore-producing bacterium, Bacillus subtilis CAS15, has a biocontrol effect on Fusarium wilt and promotes the growth of pepper. Eur. J. Soil Biol. 2011, 47, 138-145. [CrossRef]

127. Dimopoulou, A.; Theologidis, I.; Benaki, D.; Koukounia, M.; Zervakou, A.; Tzima, A.; Diallinas, G.; Hatzinikolaou, D.G.; Skandalis, N. Direct Antibiotic Activity of Bacillibactin Broadens the Biocontrol Range of Bacillus amyloliquefaciens MBI600. mSphere 2021, 6, e00376-21. [CrossRef]

128. Trapet, P.; Avoscan, L.; Klinguer, A.; Pateyron, S.; Citerne, S.; Chervin, C.; Mazurier, S.; Lemanceau, P.; Wendehenne, D.; Besson-Bard, A. The Pseudomonas fluorescens Siderophore Pyoverdine Weakens Arabidopsis thaliana Defense in Favor of Growth in Iron-Deficient Conditions. Plant Physiol. 2016, 171, 675-693. [CrossRef]

129. Maindad, D.V.; Kasture, V.M.; Chaudhari, H.; Dhavale, D.D.; Chopade, B.A.; Sachdev, D. Characterization and Fungal Inhibition Activity of Siderophore from Wheat Rhizosphere Associated Acinetobacter calcoaceticus Strain HIRFA32. Indian J. Microbiol. 2014, 54, 315-322. [CrossRef]

130. Gull, M.; Hafeez, F.Y. Characterization of siderophore producing bacterial strain Pseudomonas fluorescens Mst 8.2 as plant growth promoting and biocontrol agent in wheat. Afr. J. Microbiol. Res. 2012, 6, 6308-6318. [CrossRef]

131. Smith, M.J.; Neilands, J.B. Rhizobactin, a siderophore from Rhizobium meliloti. J. Plant Nutr. 1984, 7, 449-458. [CrossRef]

132. Meiwes, J.; Fiedler, H.; Haag, H.; Zähner, H.; Konetschny-Rapp, S.; Jung, G. Isolation and characterization of staphyloferrin A, a compound with siderophore activity from Staphylococcus hyicus DSM 20459. FEMS Microbiol. Lett. 1990, 55, 201-206. [CrossRef]

133. Das, K.; Prasanna, R.; Saxena, A.K. Rhizobia: A potential biocontrol agent for soilborne fungal pathogens. Folia Microbiol. 2017, 62, 425-435. [CrossRef]

134. De Meyer, G.; Höfte, M. Salicylic acid produced by the rhizobacterium Pseudomonas aeruginosa 7NSK2 induces resistance to leaf infection by Botrytis cinerea on bean. Phytopathology 1997, 87, 588-593. [CrossRef]

135. Audenaert, K.; Pattery, T.; Cornelis, P.; Höfte, M. Induction of systemic resistance to Botrytis cinerea in tomato by Pseudomonas aeruginosa 7NSK2: Role of salicylic acid, pyochelin, and pyocyanin. Mol. Plant-Microbe Interact. 2002, 15, 1147-1156. [CrossRef]

136. Meziane, H.; van der Sluis, I.; van Loon, L.C.; Höfte, M.; Bakker, A.H. Determinants of Pseudomonas putida WCS358 involved in inducing systemic resistance in plants. Mol. Plant Pathol. 2005, 6, 177-185. [CrossRef]

137. Schulz-Bohm, K.; Martín-Sánchez, L.; Garbeva, P. Microbial volatiles: Small molecules with an important role in intra- and inter-kingdom interactions. Front. Microbiol. 2017, 8, 2484. [CrossRef]

138. Gao, Z.; Zhang, B.; Liu, H.; Han, J.; Zhang, Y. Identification of endophytic Bacillus velezensis ZSY-1 strain and antifungal activity of its volatile compounds against Alternaria solani and Botrytis cinerea. Biol. Control 2017, 105, 27-39. [CrossRef]

139. Chaouachi, M.; Marzouk, T.; Jallouli, S.; Elkahoui, S.; Gentzbittel, L.; Ben, C.; Djébali, N. Activity assessment of tomato endophytic bacteria bioactive compounds for the postharvest biocontrol of Botrytis cinerea. Postharvest. Biol. Technol. 2021, 172, 111389. [CrossRef] 
140. Wang, C.; Wang, Y.; Wang, L.; Fan, W.; Zhang, X.; Chen, X.; Wang, M.; Wang, J. Biocontrol potential of volatile organic compounds from Pseudomonas chlororaphis ZL3 against postharvest gray mold caused by Botrytis cinerea on Chinese cherry. Biol. Control 2021, 159, 104613. [CrossRef]

141. Prigigallo, M.I.; De Stradis, A.; Anand, A.; Mannerucci, F.; L’Haridon, F.; Weisskopf, L.; Bubici, G. Basidiomycetes Are Particularly Sensitive to Bacterial Volatile Compounds: Mechanistic Insight into the Case Study of Pseudomonas protegens Volatilome against Heterobasidion abietinum. Front. Microbiol. 2021, 12, 1382. [CrossRef]

142. Simionato, A.S.; Navarro, M.O.; de Jesus, M.L.; Barazetti, A.R.; da Silva, C.S.; Simões, G.C.; Balbi-Peña, M.I.; de Mello, J.C.; Panagio, L.A.; de Almeida, R.S.; et al. The Effect of Phenazine-1-Carboxylic Acid on Mycelial Growth of Botrytis cinerea Produced by Pseudomonas aeruginosa LV Strain. Front. Microbiol. 2017, 8, 1102. [CrossRef]

143. Zhong, T.; Wang, Z.; Zhang, M.; Wei, X.; Kan, J.; Zalán, Z.; Wang, K.; Du, M. Volatile organic compounds produced by Pseudomonas fluorescens ZX as potential biological fumigants against gray mold on postharvest grapes. Biol. Control. 2021, 163, 104754. [CrossRef]

144. Ayed, A.; Kalai-Grami, L.; Slimene, I.; Chaouachi, M.; Mankai, H.; Karkouch, I.; Djebali, N.; Elkahoui, S.; Tabbene, O.; Limam, F. Antifungal activity of volatile organic compounds from Streptomyces s strain S97 against Botrytis cinerea. Biocontrol. Sci. Technol. 2021, 31, 1330-1348. [CrossRef]

145. Miles, L.A.; Lopera, C.A.; González, S.; de García, M.C.; Franco, A.E.; Restrepo, S. Exploring the biocontrol potential of fungal endophytes from an Andean Colombian Paramo ecosystem. BioControl 2012, 57, 697-710. [CrossRef]

146. Haidar, R.; Amira, Y.; Roudet, J.; Marc, F.; Patrice, R. Application methods and modes of action of Pantoea agglomerans and Paenibacillus sp. to control the grapevine trunk disease-pathogen, Neofusicoccum parvum. OENO One 2021, 55, 1-16. [CrossRef]

147. De Simone, N.; Capozzi, V.; de Chiara, M.L.; Amodio, M.L.; Brahimi, S.; Colelli, G.; Drider, D.; Spano, G.; Russo, P. Screening of lactic acid bacteria for the bio-control of botrytis cinerea and the potential of Lactiplantibacillus plantarum for eco-friendly preservation of fresh-cut kiwifruit. Microorganisms 2021, 9, 773. [CrossRef]

148. Chaudhari, S.S.; Gokhale, D.V. Phenyllactic acid: A potential aantimicrobial compound in lactic acid bacteria. J. Bacteriol. Mycol. 2016, 2, 121-125.

149. Tomsheck, A.R.; Strobel, G.A.; Booth, E.; Geary, B.; Spakowicz, D.; Knighton, B.; Floerchinger, C.; Sears, J.; Liarzi, O.; Ezra, D. Hypoxylon sp., an endophyte of Persea indica, producing 1,8-Cineole and Other Bioactive Volatiles with Fuel Potential. Microb. Ecol. 2010, 60, 903-914. [CrossRef]

150. Guigón-López, C.; Holguín-Ibarra, D.; Torres-Zapien, J.H.; García- Cruz, I.; Villapando, I.; Salas-Salazar, N.A. Metarhizium anisopliae reduces conidial germination and mycelium growth of the apple gray mold Botrytis cinerea. Biol. Control. 2021, 160, 104660. [CrossRef]

151. Singh, S.K.; Strobel, G.A.; Knighton, B.; Geary, B.; Sears, J.; Ezra, D. An Endophytic Phomopsis s Possessing Bioactivity and Fuel Potential with its Volatile Organic Compounds. Microb. Ecol. 2011, 61, 729-739. [CrossRef]

152. Fu, J.; Zhou, Y.; Li, H.F.; Ye, Y.H.; Guo, J.H. Antifungal metabolites from Phomopsis s By254, an endophytic fungus in Gossypium hirsutum. Afr. J. Microbiol. Res. 2011, 5, 1231-1236.

153. Di Francesco, A.; Zajc, J.; Gunde-Cimerman, N.; Aprea, E.; Gasperi, F.; Placì, N.; Caruso, F.; Baraldi, E. Bioactivity of volatile organic compounds by Aureobasidium species against gray mold of tomato and table grape. World J. Microbiol. Biotechnol. 2020, 36, 171. [CrossRef]

154. Huang, R.; Che, H.J.; Zhang, J.; Yang, L.; Jiang, D.H.; Li, G.Q. Evaluation of Sporidiobolus pararoseus strain YCXT3 as biocontrol agent of Botrytis cinerea on post-harvest strawberry fruits. Biol. Control 2012, 62, 53-63. [CrossRef]

155. Huang, R.; Li, G.Q.; Zhang, J.; Yang, L.; Che, H.J.; Jiang, D.H.; Huang, H.C. Control of Postharvest Botrytis Fruit Rot of Strawberry by Volatile Organic Compounds of Candida intermedia. Phytopathology 2011, 101, 859-869. [CrossRef]

156. Zou, X.; Wei, Y.; Dai, K.; Xu, F.; Wang, H.; Shao, X. Yeasts from intertidal zone marine sediment demonstrate antagonistic activities against Botrytis cinerea in vitro and in strawberry fruit. Biol. Control 2021, 158, 104612. [CrossRef]

157. Kanchiswamy, C.N.; Malnoy, M.; Maffei, M.E. Chemical diversity of microbial volatiles and their potential for plant growth and productivity. Front. Plant Sci. 2015, 6, 151. [CrossRef]

158. Insam, H.; Seewald, M.S. Volatile organic compounds [VOCs] in soils. Biol. Fertil. Soils 2010, 46, 199-213. [CrossRef]

159. Korpi, A.; Järnberg, J.; Pasanen, A.L. Microbial volatile organic compounds. Crit. Rev. Toxico. 2009, 39, 139-193. [CrossRef]

160. Nicot, C.; Stewart, A.; Bardin, M.; Elad, Y. Biological Control and Biopesticide Suppression of Botrytis-Incited Diseases. In Botrytis-The Fungus, the Pathogen and its Management in Agricultural Systems; Springer International Publishing: London, UK, 2015; pp. 165-187.

161. Gow, N.A.; Latge, J.P.; Munro, C.A. The Fungal Cell Wall: Structure, Biosynthesis, and Function. In The Fungal Kingdom; American Society of Microbiology: Washington, DC, USA, 2017; pp. 267-292.

162. Latgé, J. The cell wall: A carbohydrate armour for the fungal cell. Mol. Microbiol. 2007, 66, 279-290. [CrossRef] [PubMed]

163. Cantu, D.; Greve, L.C.; Labavitch, J.M.; Powell, A.L. Characterization of the cell wall of the ubiquitous plant pathogen Botrytis cinerea. Mycol. Res. 2009, 113, 1396-1403. [CrossRef]

164. Daulagala, W.H. Chitinolytic Endophytic Bacteria as Biocontrol Agents for Phytopathogenic Fungi and Nematode Pests: A Review. Asian J. Res. Bot. 2021, 5, 14-24.

165. Maung, C.E.; Baek, W.S.; Choi, T.G.; Kim, K.Y. Control of grey mould disease on strawberry using the effective agent, Bacillus amyloliquefaciens Y1. Biocontrol. Sci. Technol. 2021, 31, 468-482. [CrossRef] 
166. Wang, F.; Xiao, J.; Zhang, Y.; Li, R.; Liu, L.; Deng, J. Biocontrol ability and action mechanism of Bacillus halotolerans against Botrytis cinerea causing grey mould in postharvest strawberry fruit. Postharvest. Biol. Technol. 2021, 174, 111456. [CrossRef]

167. Lu, Y.; Ma, D.; He, X.; Wang, F.; Wu, J.; Liu, Y.; Jiaoa, J.; Deng, J. Bacillus subtilis KLBC BS6 induces resistance and defence-related response against Botrytis cinerea in blueberry fruit. Physiol. Mol. Plant Pathol. 2021, 114, 101599. [CrossRef]

168. Zhang, W.; Ma, J.; Yan, Q.; Jiang, Z.; Yang, S. Biochemical characterization of a novel acidic chitinase with antifungal activity from Paenibacillus xylanexedens Z2-4. Int. J. Biol. Macromol. 2021, 182, 1528-1536. [CrossRef]

169. Frankowski, J.; Lorito, M.; Scala, F.; Schmid, R.; Berg, G.; Bahl, H. Purification and properties of two chitinolytic enzymes of Serratia plymuthica HRO-C48. Arch. Microbiol. 2001, 176, 421-426. [CrossRef] [PubMed]

170. Essghaier, B.; Fardeau, M.L.; Cayol, J.L.; Hajlaoui, M.R.; Boudabous, A.; Jijakli, H.; Sadfi-Zouaoui, N. Biological control of grey mould in strawberry fruits by halophilic bacteria. J. Appl. Microbiol. 2009, 106, 833-846. [CrossRef] [PubMed]

171. Li, Z.; Chang, P.; Gao, L.; Wang, X. The Endophytic Fungus Albifimbria verrucaria from Wild Grape as an Antagonist of Botrytis cinerea and Other Grape Pathogens. Phytopathology 2020, 110, 843-850. [CrossRef] [PubMed]

172. Pachenari, A.; Dix, N.J. Production of toxins and wall degrading enzymes by Gliocladium roseum. Trans. Br. Mycol. Soc. 1980, 74, 561-566. [CrossRef]

173. Lorito, M.; Hayes, C.K.; Zoina, A.; Scala, F.; Del Sorbo, G.; Woo, S.L.; Harman, G.E. Potential of genes and gene products from Trichoderma s and Gliocladium s for the development of biological pesticides. Mol. Biotechnol. 1994, 2, 209-217. [CrossRef]

174. Elad, Y.; Kapat, A. The Role of Trichoderma harzianum Protease in the Biocontrol of Botrytis cinerea. Eur. J. Plant Pathol. 1999, 105, 177-189. [CrossRef]

175. Heyens, K.; Aerts, R.; Seels, B.; Vogels, L.; Bruno, A. Biological control of Botrytis cinerea in tomato. Acta Hortic. 2011, 914, 361-363. [CrossRef]

176. Zhang, D.; Spadaro, D.; Valente, S.; Garibaldi, A.; Gullino, M.L. Cloning, characterization, expression and antifungal activity of an alkaline serine protease of Aureobasidium pullulans PL5 involved in the biological control of postharvest pathogens. Int. J. Food Microbiol. 2012, 153, 453-464. [CrossRef]

177. Friel, D.; Gomez Pessoa, N.M.; Vandenbol, M.; Jijakli, M.H. Separate and combined disruptions of two exo-beta-1,3-glucanase genes decrease the efficiency of Pichia anomala [strain K] biocontrol against Botrytis cinerea on apple. Mol. Plant Microbe Interact. 2007, 20, 371-379. [CrossRef]

178. Lima, G.; de Curtis, F.; Piedimonte, D.; Spina, A.M.; de Cicco, V. Integration of biocontrol yeast and thiabendazole protects stored apples from fungicide sensitive and resistant isolates of Botrytis cinerea. Postharvest Biol. Technol. 2006, 40, 301-307. [CrossRef]

179. Kredics, L.; Antal, Z.; Szekeres, A.; Hatvani, L.; Manczinger, L.; Vágvölgyi, C.; Nagy, E. Extracellular proteases of Trichoderma species: A review. Acta Microbiol. Immunol. Hung. 2005, 52, 169-184. [CrossRef]

180. De Simone, N.; Pace, B.; Grieco, F.; Chimienti, M.; Tyibilika, V.; Santoro, V.; Capozzi, V.; Colelli, G.; Spano, G.; Russo, P. Botrytis cinerea and Table Grapes: A Review of the Main Physical, Chemical, and Bio-Based Control Treatments in Post-Harvest. Foods 2020, 9, 1138. [CrossRef]

181. Salvatierra-Martinez, R.; Arancibia, W.; Araya, M.; Aguilera, S.; Olalde, V.; Bravo, J.; Stoll, A. Colonization ability as an indicator of enhanced biocontrol capacity-An example using two Bacillus amyloliquefaciens strains and Botrytis cinerea infection of tomatoes. J. Phytopathol. 2018, 166, 601-612. [CrossRef]

182. Zhou, C.; Zhu, J.; Qian, N.; Guo, J.; Yan, C. Bacillus subtilis SL18r Induces Tomato Resistance Against Botrytis cinerea, Involving Activation of Long Non-coding RNA, MSTRG18363, to Decoy miR1918. Front. Plant Sci. 2021, 11, 2317. [CrossRef]

183. Miotto-Vilanova, L.; Jacquard, C.; Courteaux, B.; Wortham, L.; Michel, J.; Clément, C.; Barka, E.A.; Sanchez, L. Burkholderia phytofirmans PsJN Confers Grapevine Resistance against Botrytis cinerea via a Direct Antimicrobial Effect Combined with a Better Resource Mobilization. Front. Plant Sci. 2016, 7, 1236. [CrossRef]

184. Chen, C.; Cao, Z.; Li, J.; Tao, C.; Feng, Y.; Han, Y. A novel endophytic strain of Lactobacillus plantarum CM-3 with antagonistic activity against Botrytis cinerea on strawberry fruit. Biol. Control 2020, 148, 104306. [CrossRef]

185. Gasser, F.; Cardinale, M.; Schildberger, B.; Berg, G. Biocontrol of Botrytis cinerea by successful introduction of Pantoea ananatis in the grapevine phyllosphere. Int. J. Wine Res. 2012, 4, 53-63.

186. Van Loon, L.C. Induced resistance in plants and the role of pathogenesis-related proteins. Eur. J. Plant Pathol. 1997, 103, 753-765. [CrossRef]

187. Islam, A.; Kabir, S.; Khair, A. Characterization and evaluation of Bacillus siamensis isolate for its growth promoting potential in tomato. Agriculture 2019, 65, 42-50. [CrossRef]

188. Mari, M.; Guizzardi, M.; Pratella, G.C. Biological control of gray mold in pears by antagonistic bacteria. Biol. Control. 1996, 7, 30-37. [CrossRef]

189. Sutton, J.C.; Peng, G. Biocontrol of Botrytis cinerea in Strawberry Leaves. Phytopathology 1993, 83, 615-621. [CrossRef]

190. Liu, C.M.; Liu, S.Y.; Liao, C.K.; Lo, C.T.; Lin, K.C.; Peng, K.C. Cabbage defense response provoked by Trichoderma Th-LAAO. Arch. Microbiol. 2021, 203, 1641-1647. [CrossRef]

191. Fiori, S.; Fadda, A.; Giobbe, S.; Berardi, E.; Migheli, Q. Pichia angusta is an effective biocontrol yeast against postharvest decay of apple fruit caused by Botrytis cinerea and Monilia fructicola. FEMS Yeast Res. 2008, 8, 961-963. [CrossRef]

192. Hamdache, A.; Ezziyyani, M.; Lamarti, A. Effect of preventive and simultaneous inoculations of Bacillus amyloliquefaciens [Fukumoto] strains on conidial germination of Botrytis cinerea Pers. Fr. An Biol. 2018, 40, 65-72. [CrossRef] 
193. Raynaldo, F.A.; Dhanasekaran, S.; Ngea, G.L.; Yang, Q.; Zhang, X.; Zhang, H. Investigating the biocontrol potentiality of Wickerhamomyces anomalus against postharvest gray mold decay in cherry tomatoes. Sci. Hortic. 2021, 285, 110137. [CrossRef]

194. Ingold, C.T.; Hudson, H.J.; Ingold, C.T.; Hudson, H.J. Fungi as Plant Pathogens. In The Biology of Fungi; Springer: Dordrecht, The Netherlands, 1993; pp. 159-182.

195. Hernández-Fernández, M.; Cordero-Bueso, G.; Ruiz-Muñoz, M.; Cantoral, J.M. Culturable yeasts as biofertilizers and biopesticides for a sustainable agriculture: A comprehensive review. Plants 2021, 10, 822. [CrossRef]

196. Hilber-Bodmer, M.; Schmid, M.; Ahrens, C.H.; Freimoser, F.M. Competition assays and physiological experiments of soil and phyllosphere yeasts identify Candida subhashii as a novel antagonist of filamentous fungi. BMC Microbiol. 2017, 17, 4. [CrossRef]

197. Kloepper, J.W.; Schippers, B.; Bakker, A.H. Proposed Elimination of the Term Endorhizosphere. Phytopathology 1992, 82, 726-727.

198. Ferrari, S.; Galletti, R.; Denoux, C.; De Lorenzo, G.; Ausubel, F.M.; Dewdney, J. Resistance to Botrytis cinerea induced in arabidopsis by elicitors is independent of salicylic acid, ethylene, or jasmonate signaling but requires Phytoalexin Deficient3. Plant Physiol. 2007, 144, 367-379. [CrossRef]

199. Govrin, E.M.; Levine, A. Infection of Arabidopsis with a necrotrophic pathogen, Botrytis cinerea, elicits various defense responses but does not induce systemic acquired resistance [SAR]. Plant Mol. Biol. 2002, 48, 267-276. [CrossRef]

200. Vallad, G.E.; Goodman, R.M. Systemic acquired resistance and induced systemic resistance in conventional agriculture. Crop Sci. 2004, 44, 1920-1934. [CrossRef]

201. Peng, K.C.; Lin, C.C.; Liao, C.F.; Yu, H.C.; Lo, C.T.; Yang, H.H.; Lin, K.C. Expression of L-amino acid oxidase of Trichoderma harzianum in tobacco confers resistance to Sclerotinia sclerotiorum and Botrytis cinerea. Plant Sci. 2021, 303, 110772. [CrossRef] [PubMed] 